\title{
Current perspective of yellowish-orange pigments from microorganisms- a review
}

\author{
Claira Arul Aruldass ${ }^{a}$, Laurent Dufossé ${ }^{b}$, Wan Azlina Ahmad ${ }^{\mathrm{a}}$ * $^{\text {* }}$
}

a Department of Chemistry, Faculty of Science, Universiti Teknologi Malaysia, 81310, UTM, Johor Bahru, Johor, Malaysia

${ }^{\mathrm{b}}$ Université de La Réunion, Laboratoire de Chimie des Substances Naturelles et des Sciences des Aliments, Ecole Supérieure d'Ingénieurs Réunion Océan Indien, Département Innovation et Développement Agroalimentaire Intégré, ESIROI-IDAI, 2 rue Joseph Wetzell, Parc Technologique Universitaire, F-97490, Sainte-Clotilde, Ile de La Réunion, France

Natural yellowish-orange pigments are derived from bacteria, yeasts, fungi and microalgae, including Chryseobacterium, Monascus and Chlorella. The purpose of this review is to provide an overview of these pigments in various aspects towards exploiting them for numerous functions. These pigments are pro-duced in various shades of yellow-orange and categorised as carotenoids, anthraquinones, zeaxanthin, flexirubin and other compounds. They served as alternative colourants to replace hazardous and toxic synthetic pigments. Researchers are in progress to increase the pigment yield by improving the strains genetically, optimising the fermentation process and utilising cheap agroindustrial waste to reduce the production cost. Yellowish-orange pigments are applied in food, pharmaceuticals, cosmetics and textile industries. This review summarises the current technology status and challenges, economics, biosyn-thesis of pigment, novel strategies for production of yellowish-orange pigments, biological properties of pigments and metabolic engineering of microorganism with a focus on applications of pigments in food, pharmaceutical, dyeing industries as well as on other applications.

\section{Contents}

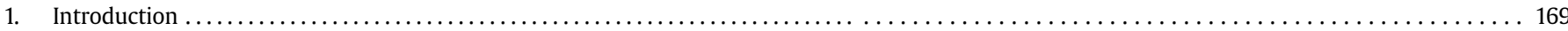

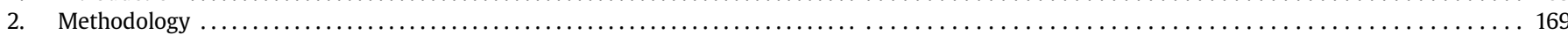

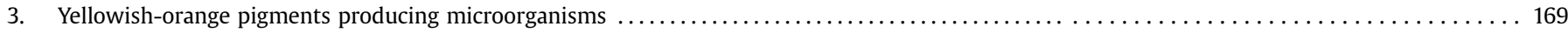

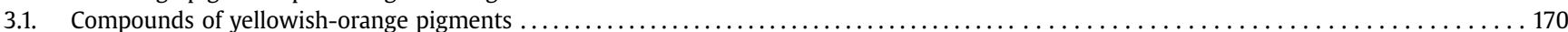

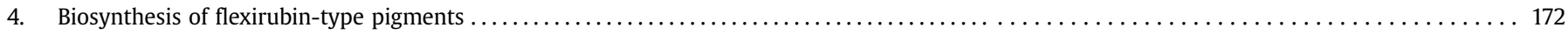

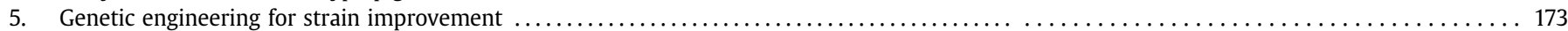

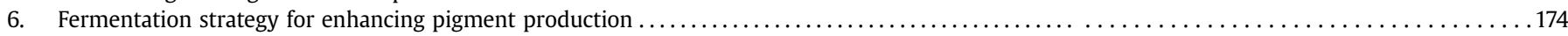

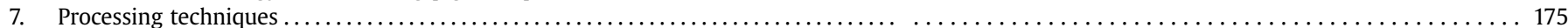

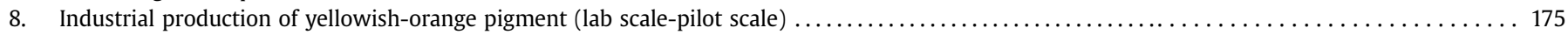

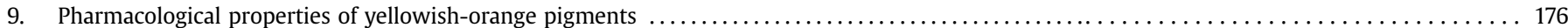

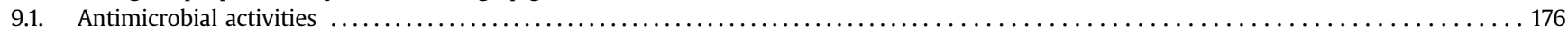

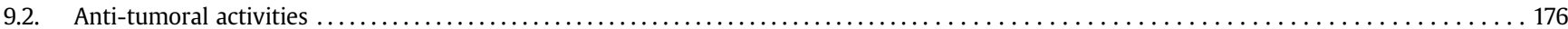

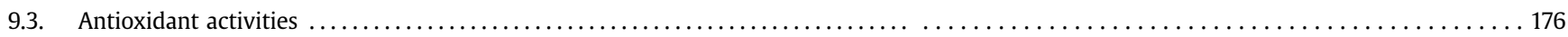

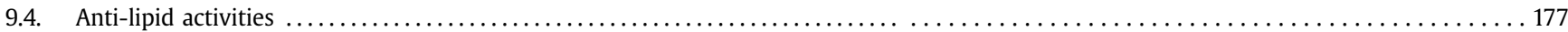

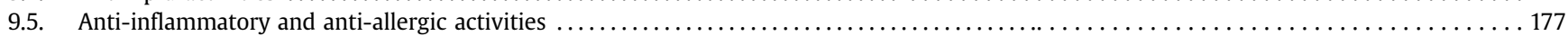

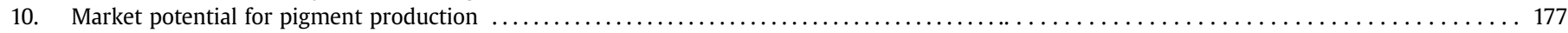

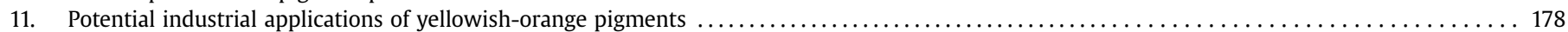

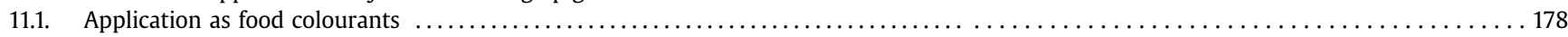

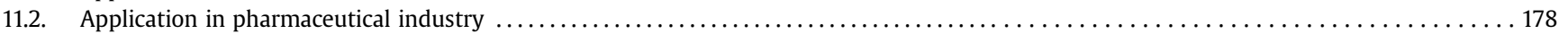

\footnotetext{
* Corresponding author.

E-mail address: azlina@kimia.fs.utm.my (W.A. Ahmad).
} 


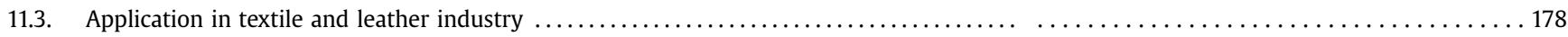

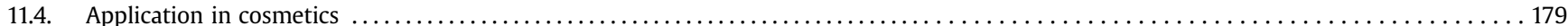

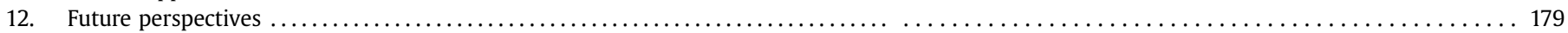

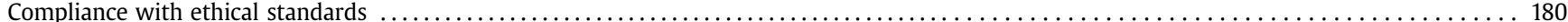

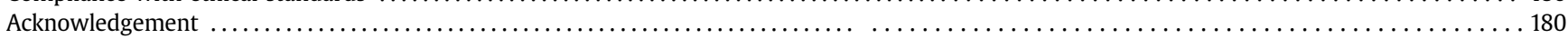

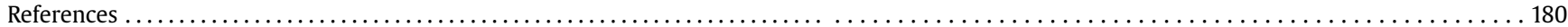

\section{Introduction}

As current inclinations towards health concerns are on rise, nontoxic resources are taken into consideration in various industrial fields. Natural pigments, derived from plants, insects or animals, minerals and microorganisms are biodegradable, renewable, environmental friendly and known for their use in textile dyeing, food ingredients, cosmetics and pharmaceutics (Shahid et al., 2013). Even though synthetic dyes, such as tartrazine, carmoisine used in food industries offer vibrant yellow and red colours, they are notoriously toxic (hepatocellular damage) for human consumption (Amin et al., 2010). Thus, natural pigments serve as potential viable "Green chemistry" to replace synthetic dyes (Yusuf et al., 2011). Among these pigments, carotenoids from plant sources have been extensively studied and reviewed. However, reviews on yellowishorange pigments produced from microorganisms were still shallow. This review presents comprehensive information about the strains that produce yellowish-orange pigments, biosynthetic pathway of flexirubin production, current technology status and challenges, economics, novel strategies for production of yellowishorange pigments, biological properties of pigments and metabolic engineering of microorganism with a focus on applications of pigments in food, pharmaceutical, dyeing industries as well as on other applications.

Yellowish-orange pigments occur widely in nature and in general, fruits, vegetables, microorganisms and microalgae are good sources of this pigment. This pigment is responsible for shades of red, orange and yellow of plant leaves, fruits, flowers, birds, insects, fish and crustaceans (Eldahshan and Singab, 2013). Some familiar examples of yellowish-orange compounds are carotenoids, flexirubin, ankaflavin and anthraquinones. In plants, orange of carrot, citrus fruits and saffron, the red of peppers and tomatoes, yellow of corn, mango, turmeric and marigold flowers are due to the presence of carotenoid compounds. In animals, the presence of astaxanthin and canthaxanthin compounds in flamingos, salmon, shrimp and lobsters show pink reddish-orange colourant of the animals (Mezzomo and Ferreira, 2016).

Various microorganisms also produce pigments with colours ranged from red to orange and they are categorised as carotenoids, flexirubin and other compounds. Examples of microorganisms that produce these carotenoids are Nannochloropsis gaditana (astaxanthin, $\beta$-carotene), Dietzia natronolimnaea HS-1 and Chlorella zofingiensis (canthaxanthin), Rhodoturula glutinis ( $\beta$-carotene), Monascus sp. (ankaflavin, monascorubramin), Ashbya gossypi (riboflavin), and Penicillium oxalicum (anthraquinone) (Cardoso et al., 2017). Besides microorganisms, microalgaes, namely Chlamydomonas reinhardtii and Chlorella zofingiensis produce natural yellowish-orange pigments such as $\alpha$-carotene, lutein, zeaxanthin, anteraxanthin, neoxanthin and violaxanthin (Mulders, 2014).

Although some natural yellowish-orange pigments are already available, pigments from microorganism play a vital role for this pigment production due to its advantage over plants in terms of availability, stability and easy down streaming process (Tuli et al., 2014). Pigment production is also cheaper and higher yields could be obtained through strain improvement. Pigments also possess various pharmacological activities such as antioxidant, anticancer and antimicrobial activities. In line with that, natural pigments serve as alternative colouring agents are in demand in industries such as textile, plastic, paint, paper and printing (Tuli et al., 2014).

\section{Methodology}

While researchers such as Dufossé et al. (2014) and Venil et al. (2014a, 2013) have identified the sustainability benefits of microorganism pigments and their advancements in fermentation in general, it is important to focus on particular pigment, yellowishorange pigment and examine its potential benefits and applications. This paper investigates the current challenges, economics, novel strategies and application of yellowish-orange pigment from microorganisms through exploratory reports and studies on this pigment.

The information was identified through reports and reviews for yellowish-orange pigment for various microorganisms. Most of the reports were based on yellow pigments from fungus, including Monascus sp. and yeast. Although various reviews were found for carotenoids, zeaxanthin and ankaflavin, least studies were carried out for flexirubin-type pigments.

A list of microorganisms producing yellowish-orange pigment, the source of strain isolation and country was adopted from various resources and listed in Table 1 . The compounds present in yellowish-orange pigment and the biosynthesis of flexirubin were discussed in Section 3 and 4. The strategies for strain improvement and fermentation for high pigment production were summarised in Section 5 and 6. Processing techniques, pilot scale production and pharmacological activities of pigment were discussed in Section 7, 8 and 9, respectively. Market potential and the pigment applications in various fields were described in Section 10 and 11. An overall summary and future perspectives of the yellowish-orange pigment were provided at the end of Section 12.

\section{Yellowish-orange pigments producing microorganisms}

Natural yellowish-orange pigments are produced by diverse genera of microorganisms, including bacteria, yeasts, filamentous fungi (Berman et al., 2015) and microalgae (Henríquez et al., 2016). These yellow pigments producers are varied phylogenetically and the production depends on the location of isolated microorganisms. As shown in Table 1, these include quite a selection of environs as these microorganisms have been found associated with the soil and water.

Most recently, there have been different strategies for studying yellow pigment producers in different parts of the world. Venil et al. (2014b) isolated and identified Chryseobacterium artocarpi CECT 8497 from rhizosphere soil of Artocarpus integer. The bacteria produce yellowish-orange pigment which belongs to flexirubin type. The16S rRNA gene sequences and DNA-DNA hybridization test demonstrated that this strain constituted a distinct phyletic 
Table 1

Yellowish-orange pigment production from various microorganisms.

\begin{tabular}{|c|c|c|c|}
\hline Strains & Pigment colour & Comments & References \\
\hline Microbacterium oxydans & $\begin{array}{l}\text { Yellow } \\
\text { (Carotenoids) }\end{array}$ & Wood decay, Canada & $\begin{array}{l}\text { Meddeb-Mouelhi et al., } \\
2016\end{array}$ \\
\hline Chryseobacterium rhizoplanae JM- $534^{\mathrm{T}}$ & Yellow & Rhizoplane of Zea mays field, United States & Kämpfer et al., 2015 \\
\hline Flavobacterium maris KMM $9535^{\mathrm{T}}$ & Yellow & Seashore sediment, Japan & Romanenko et al., 2015 \\
\hline Chryseobacterium zeace JM- $1085^{\mathrm{T}}$ & Yellow & Spelt of Zea mays, United States & Kämpfer et al., 2014 \\
\hline Chryseobacterium arachidis $91 \mathrm{~A}-593^{\mathrm{T}}$ & Yellow & Arachis hypogaea, United States & \\
\hline $\begin{array}{l}\text { Chryseobacterium geocarposphaerae } 91 \mathrm{~A}- \\
561^{\mathrm{T}}\end{array}$ & Yellow & $\begin{array}{l}\text { Geosphere of soil of immature groundnuts, United } \\
\text { States }\end{array}$ & \\
\hline Rubritalea squalenifaciens sp. nov & $\begin{array}{l}\text { Yellow } \\
\text { (Carotenoids) }\end{array}$ & Marine, Japan & Shindo and Misawa, 2014 \\
\hline Chryseobacterium acrtocarpi CECT 8497 & $\begin{array}{l}\text { Yellowish-orange (Flexirubin type } \\
\text { pigment) }\end{array}$ & Rhizosphere soil, Malaysia & Venil et al., 2014b \\
\hline Flavobacterium tilapiae Ruye- $71^{\mathrm{T}}$ & Yellow & Freshwater pond, Taiwan & Chen et al., 2013 \\
\hline Monascus sp. & $\begin{array}{l}\text { Yellow } \\
\text { (Ankaflavin) }\end{array}$ & Collection & Hsu et al., 2013 \\
\hline Staphylococcus kloosii & Orange & Respiratory tree, Malaysia & Kamarudin et al., 2013 \\
\hline $\begin{array}{l}\text { Exiguobacterium } \\
\text { aurantiacum and Exiguobacterium } \\
\quad \text { profundum }\end{array}$ & Yellow & Soil and air, India & Sasidharan et al., 2013 \\
\hline Alternaria sp. & Yellow (Pyscion and macrosporin) & Fruit of marine mangrove tree, China & Huang et al., 2011 \\
\hline Eurotium rubrum & Yellow (Asperflavin) & Stem of marine mangrove tree, China & Li et al., 2009 \\
\hline Pseudomonas argentinensis $\mathrm{CH}_{0}{ }^{\mathrm{T}}$ & Yellow & Rhizospheric soil, Argentina & Peix et al., 2005 \\
\hline Rhodotorula glutinis & $\begin{array}{l}\text { Yellowish pink } \\
\text { (Carotenoids) }\end{array}$ & Refinery wastewater, Turkey & Aksu and Eren, 2007 \\
\hline
\end{tabular}

line within the genus Chryseobacterium, which is a distinct novel genomic species. The isolate was a non-spore-forming, rod-shaped Gram negative bacterium with flagellum and form yellowish, translucent and shiny edges of colonies.

In the work of Shindo and Misawa (2014), a novel yellow pigment producing bacterium (strain $\mathrm{HOact}^{2} 3^{\mathrm{T}}$ ) was isolated from marine sponge Halicaondria okadai in Japan and identified as Rubritalea squalenifaciens. Rubritalea squalenifaciens was found to produce squalene and new acyclic $\mathrm{C}_{30}$ carotenoids, diapolycopenedioc acids xylosylesters $\mathrm{A}-\mathrm{C}$ with strong antioxidant activities. These $C_{30}$ carotenoids act as promising functional carotenoids. The bacterium is likely to produce carotenoids for protection from activated oxygen produced by sunlight which may contribute to strong antioxidant activity.

Flavobacterium tilapiae Ruye- $71^{\mathrm{T}}$ was isolated from Taiwan freshwater tilapiine cichlid fish culture pond (Chen et al., 2013). This aerobic rod-shaped Gram negative bacterium belonged to the genus Flavobacteirum and closely related to Flavobacterium defluvii $\mathrm{EMB}_{117}{ }^{\mathrm{T}}$. This isolate forms bright yellow, slightly sticky, convex and circular with irregular, curled margins colonies. The authors proposed that strain Ruye- $71^{\mathrm{T}}$ was a novel species of Flavobacterium, for which the name Flavobacterium tilapiae was given.

Alternaria sp. ZJ9-6B, endophytic fungus was isolated from fruit of marine mangrove tree Aegiceras corniculatum in Zhanjiang, Guangdong (South China Sea), China (Huang et al., 2011). This fungus is known to produce nine metabolites, including yellow physcion and macrosporin and three new anthraquinone derivatives. Li et al. (2009) isolated an endophytic fungus, Eurotium rubrum from inner tissue of stems of Hibiscus tiliaceus near Hainan Island, China. This fungus is reported to produce a yellow asperflavin as one of its secondary metabolites.

To our opinion, screening efforts should be strengthened during the next years to enlarge the number of microorganisms under study by academic groups and companies. Multidisciplinary teams (microbiologists, taxonomists, molecular biologists, chemical analysts, spectroscopists, fermentation technologists, extraction specialists, formulators, toxicologists) should be built in order to have faster industrial developments of yellowish-orange pigments.

\subsection{Compounds of yellowish-orange pigments}

Yellowish-orange pigments produced by microorganisms are in range of yellow-orange to pink red including flexirubin, ankaflavin, astaxanthin and $\beta$-carotene (Fig. 1) (Jehlička et al., 2013). The presence of chromophore structures (10 and $\mathbf{1 1}$ ) are the key components responsible for the colours of pigments (Fig. 1A). Besides these compounds, phenazines (12 to $\mathbf{1 4}$ ) from eubacteria also give natural yellow, orange brick red pigments and these compounds have heterocylic nitrogen structures (Fig. 1A). Phenazines producing species are mainly Pseudomonas fluorescens, Pseudomonas chloraraphis, Pseudomonas aeruginosa and Pantoea agglomerans Eh1087 (Mavrodi et al., 2006).

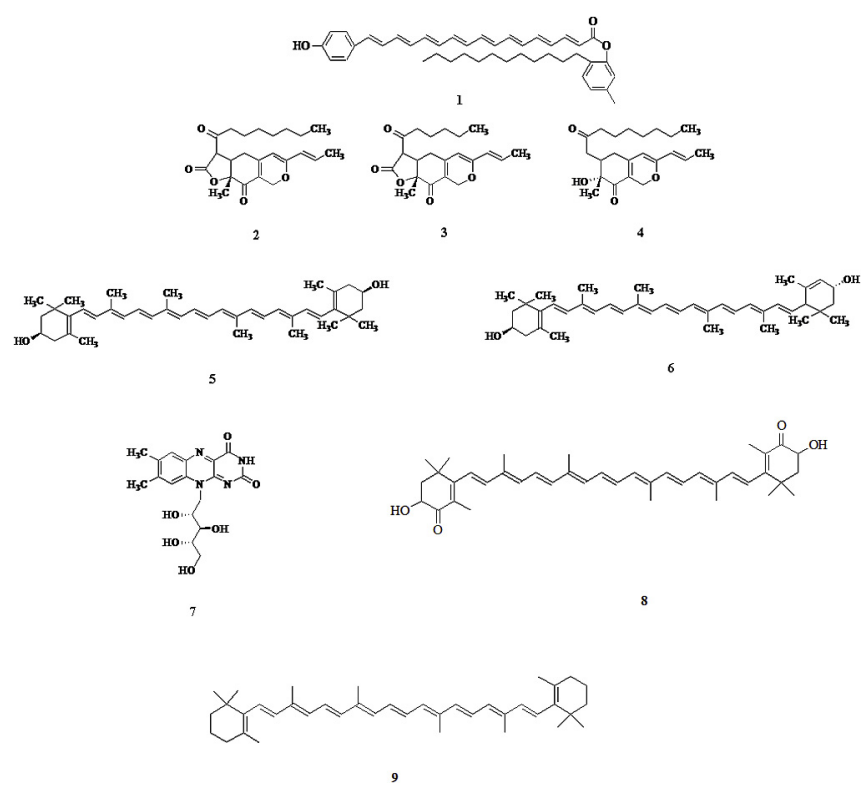

Fig. 1. Structure of yellowish-orange pigments: flexirubin (1), ankaflavin (2), monaphilone A (3), zeaxanthin (4), lutein (5), astaxanthin (6), $\beta$-carotene (7), riboflavin (8) and azaphilones $(\mathbf{9})$ 
<smiles>Cc1ccccc1O</smiles>

10<smiles>Oc1ccccc1</smiles>

11<smiles>O=C(O)c1cccc2nc3ccccc3nc12</smiles>

12<smiles>C[n+]1c2ccccc2nc2c(O)cccc21</smiles>

13

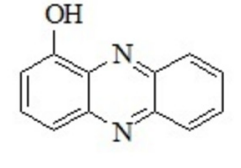

14
Fig. 1A. Structure of chromophores ( $\mathbf{1 0}$ and 11), structure of phenazines: phenazine-1carboxylic acid (PCA) (12), pyocyanin (13) and 1-hydroxyphenazine (14).

Yellowish-orange pigment exists in various shades of yellow colour (Fig. 2A) and various tools, such as visible light or colour meter are used to categorise it. As shown in Fig. 2B and C, $L^{*} a^{*} b^{*}$ system colour space and visible spectrum are among the tools to determine the colour of pigments, respectively. Yellowish-orange colour falls within the wavelength ranged from 570 to $590 \mathrm{~nm}$. The colour of yellowish-orange pigments is determined by colour space which perceived the elements of lightness, hue angles and chroma values from the $L^{*} a^{*} b^{*}$ coordinates. The $L^{*}$ coordinate measures the value of lightness and ranges from black $(0)$ at the bottom to white (100) at top. Values of $a^{*}$ and $b^{*}$ indicate directions away from the center of colour sphere where $a^{*}$ coordinate denotes red when positive and green when negative. Meanwhile $b^{*}$ coordinate indicates yellow when positive and blue when negative. A sample with hue angle $0^{\circ}$ is purplish-red, $90^{\circ}$ is yellow, $180^{\circ}$ is bluish green and $270^{\circ}$ is blue. Chroma is the colour saturation or purity as high chroma is more vivid than one with lower chroma value (Fig. 2B).

Yongsmith et al. (2013) reported on the colour values of spray dried yellow pigment produced by Monascus using golden brown rice, including $L^{*}$, chroma value and hue angle of 74.63, 28.97 and $73.70^{\circ}$, respectively. Monascus fungus produces pigments in the range of orange-red hues, including lutein (yellow) with hue angle of $95.3^{\circ}$ and carotene (yellow) with hue angle of $99.3^{\circ}$. Other yellow pigments, namely annatto, turmeric carthamus had hue angles ranging from $105^{\circ}$ to $110^{\circ}$, representing green-yellow colour. Highest chroma value of 41 and 38 were observed for annatto, natural carotene and yellow pigment from Monascus, respectively (Mapari et al., 2006). Another approach was carried out by Jung et al. (2003) by determining the colour values of pigments produced by Monascus upon adding various amino acids as nitrogen sources during fermentation. Pigments produced have positive values of $L^{*} a^{*} b^{*}$ indicating yellowness and redness of the pigments.

of interest, flexirubin type pigments fall within the range of yellowish-orange shades and few methods were demonstrated by Fautz and Reichenbach (1980) to distinguish flexirubin type pigments from carotenoid pigments. Crude flexirubin type pigments are yellow and reversible as the colour change to red, purple or brown observed upon treating with alkaline solution such as potassium hydroxide ( $\mathrm{KOH})$. Presence of polyene chromophore and phenolic hydroxyl group ( $\mathbf{1 0}$ and $\mathbf{1 1}$ ) was responsible for the colour shift in flexirubin type pigments; however, it was not applicable for slightly modified flexirubin pigments such as methylation of the hydroxyl group.

New approaches including incorporation of labelled biosynthetic precursors into pigment and autoradiographic analysis of chromatogram were carried out to identify slightly modified flexirubin pigments. Observation of methionine and tyrosine spots on chromatogram indicates the flexirubin type pigments as these spots were not present in carotenoid, zeaxanthin pigment. As tyrosine is the origin of chromophore structures and methyl group derived from methionine during biosynthesis of flexirubin, these spots distinguish the flexirubin type pigments from other yellowish-orange compounds that may have similar structures.

Despite the number of structures already described in the literature, as shown in the previous paragraphs, many structures of
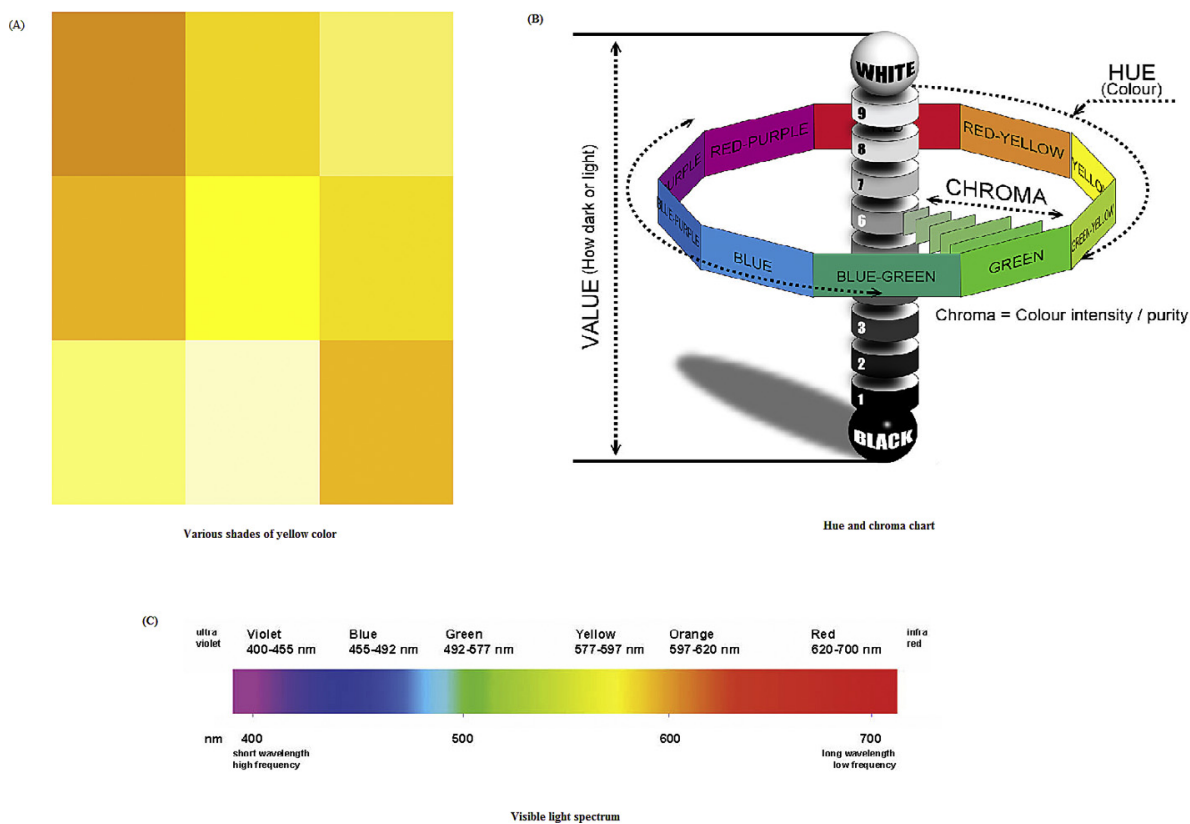

Fig. 2. Shades of yellow colour (A), hue and chroma chart (B) and visible spectrum (C). 
microbial yellowish-orange pigments remain completely unknown or partially described. Sometimes the published researches about these pigments were only conducted by microbiologists who are not aware of fine chemical structure analyses. To our opinion, chemists could easily bring useful information about many microbial yellowish-orange pigments which remain completely unknown or partially described.

\section{Biosynthesis of flexirubin-type pigments}

Flexirubin-type pigments have been used as chemotaxonomic markers for the bacteria of the Bacteroidetes phylum (previously called the Cytophaga-Flavobacterium-Bacteroides group) (Schöner et al., 2014). Flexirubin pigments have unique structures containing aryl polyenes with a polyenoic acid chromophore which is termintated by a $p$-hydroxyphenyl group and esterified with a dialkylated resorcinol (DAR) (Fig. 3).

Achenbach et al. (1978) was the first to report on evidence of flexirubin biosynthetic pathway. A precursor, tyrosine and methyl group that derived from methionine form the polyene chain of flexirubin as acetate, conjugated phenyl and three adjacent carbon atoms were also involved in the biosynthesis (Achenbach et al., 1978). It was also proposed that polyketide biosynthesis mechanism is involved during the incorporation of acetate and malonate (Fautz and Reichenbach, 1979). There are possible ways that polyene chain length can be varied namely, upon addition of six and eight double bonds, the presence or absence of a methyl- or chlorosubstituent in the meta position of the conjugated phenyl groups and in the alkyl substituent of the esterified resorcinol.

Schöner et al. (2015) worked on DAR biosynthesis, a spontaneous decarboxylation of 4-carboxy-CHD resulted in the formation of 2,5-dialkylcyclohexane-1,3-diones (CHD) (Fig. 4). The 4-carboxyCHD is formed during the cyclization of $\beta$-keto-acyl precursor with $\alpha, \beta$-unsaturated acyl precursor which was catalysed by enzyme ketosynthase (KS) DarB. It was postulated that fatty acid catabolism intermediates involved in DAR biosynthesis pathway as anabolic chain elongation of DarB converting myristoyl-CoA to $\beta$ -<smiles>CCCCCc1cc(O)c(CCCCCCCCC(C)C)c(OC(=O)/C=C/C=C/C=C/C=C/C=C/C=C/C=C/C=C/c2ccc(O)cc2)c1</smiles>

15<smiles>CCCCCCCCCCCCc1c(O)cc(C)cc1OC(=O)/C=C/C=C/C=C/C=C/C=C/C=C/C=C/c1ccc(O)c(C)c1</smiles>

16

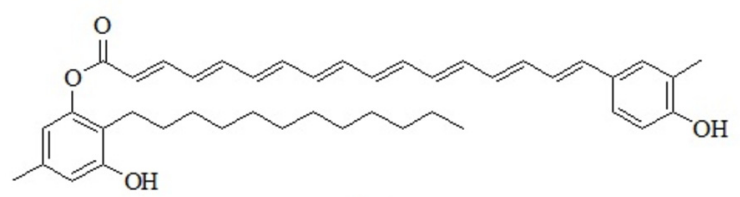

17

Fig. 3. Structure of flexirubin compounds from Flavobacterium johnsoniae (15), Flexibacter elegans (16) and Chirinophaga filiformis (17) (Schöner et al., 2014).

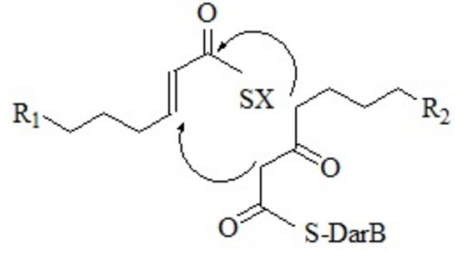<smiles>[R]CCCC1CC(=O)C(CCC[R])C(C(=O)O)C1=O</smiles><smiles>CC(C)(N)C(=O)O</smiles><smiles>[R]CCCC1CC(=O)C(CCC[R])C(=O)C1</smiles>

2,5-dialkylcyclohexane-1,3-dione

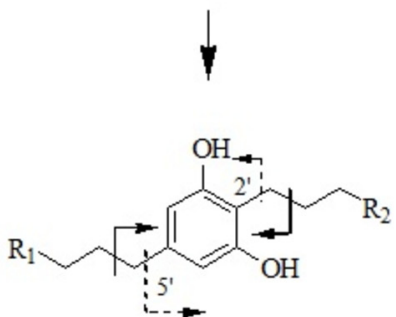

Fig. 4. Proposed DAR biosynthesis. DarB catalyzes the cyclization of a $\beta$-keto-acy precursor with an $\alpha, \beta$-unsaturated acyl precursor to form the 4-carboxy-CHD. CHD was formed due to spontaneous hydrolysis and decarboxylation. In the final step, DarA oxidizes either 4-carboxy-CHD, CHD or both to the corresponding DAR derivative. The fragmentation patterns of a soft (broken arrows) and hard ionization (continuous arrow) for DARs are indicated (S is CoA or ACP bound) (Schöner et al., 2015).

ketopalmitoyl-CoA was undetectable. Fuchs et al. (2013) also reported similar mechanism for DAR moiety formation by condensation of two fatty acid metabolisms; however the enzymes that involved are still unknown.

Schöner et al. (2014) also reported on flexirubin biosynthesis of Chitinophaga pinensis and characterisation of tyrosine ammonia lyases (TAL) and 4-coumarate-CoA ligases (4CL) for polyene biosynthesis. Expression of genes darB (Cpin_6850) and darA (Cpin_6851) from C. pinensis leads to the production of DAR, which is identical to DAR moiety in flexirubin in C. filiformes (Fuchs et al., 2013) (Fig. 5A). Similarly, mutated darB and additional genes of Flavobacterium johnsoniae also resulted in flexirubin-negative phenotype which involved in flexirubin biosynthesis (Fig. 5B) (Mc Bride et al., 2009). Franceschini et al. (2013) found similar gene cluster spanning Cpin_1853 (flxA) to Cpin_1877 (flxY) for C. pinensis and $F$. johnsoniae flexirubin gene cluster.

Type II fatty acid synthase-like biosynthesis of flexirubin polyene moiety was formed with the involvement of several putative $\beta$ ketoacyl synthases, reductases, dehydrateses and thioesterases. Polyene-aryl and adjacent double bond of flexirubin were derived from tyrosine (Achenbach et al., 1979) and L-tyrosine has higher specificity towards FlxA during ammonia-lyases activity in 

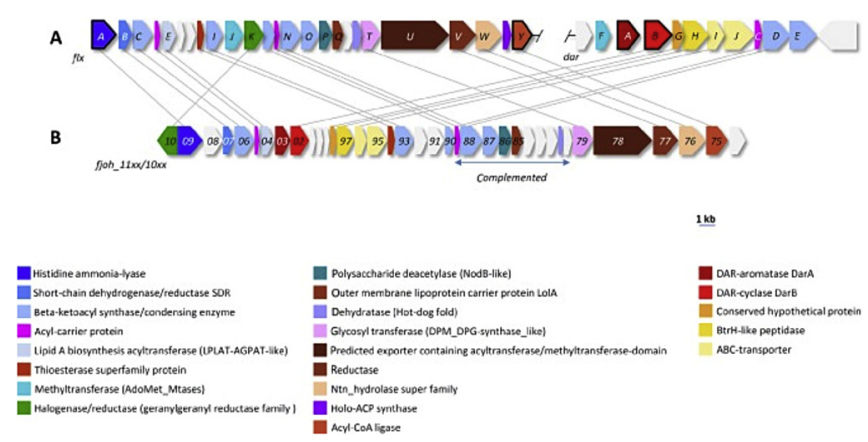

Fig. 5. Postulated biosynthesis of flexirubin in Chitinophaga pinensis (A) and Flavobacterium johnsoniae UW101 (B) by known and proposed gene clusters (Schöner et al., 2014).

flexirubin biosynthesis (Schöner et al., 2014). Polyketide synthase (PKS) was activated by the formation of 4-cinnamic acid (CA) from deamination of L-tyrosine catalysed by FlxA. Acyl-CoA ligase FlxY catalysed the adeylation of PKS and a precursor, 4-coumaryl-CoA is used for a fatty acid-like biosynthesis by chain elongation through the putative - $\beta$ ketoacyl synthases (FlxC, FlxI, FlxL, FlxN, FlxO). $\beta$ keto function is reduced by FlxB or FlxV and double bond is generated by a dehydratase (FlxF, FlxS). The aryl-octaene moiety attached to the DAR by a ligase-like enzyme (FlxW) to form flexirubin (Fig. 6).

\section{Genetic engineering for strain improvement}

Natural pigments from microorganisms were limited for industrial fields as the wild strains were prone to produce pigments at low concentration. Strains development using genetic engineering approach is worth to increase the pigment production. As biotechnological industries are at the fast growth phase, shorter fermentation with high pigment yields is essential for industries. Advancement of microbiology was implemented by identifying bacterial strains with desired traits with the knowledge of biochemistry, chemical engineering and physiology (Venil et al., 2014a). Manipulation and alteration of sequence of genes in the DNA of bacterial strains were attempted to enhance the bacterial metabolism and increase the product yields. Mutagenesis techniques were used to create genetic mutations such as ultraviolet (UV) irradiation that affect the production of metabolites and characteristics of pigmented bacteria (Awan et al., 2011).

Strategies for hyper-production of bacterial pigments using mutagenesis in bacterial strains by physical mutagens such as UV irradiation are well documented. Recently, Yolmeh et al. (2017) reported on the optimisation of carotenoid pigment production from Micrococcus roseus under UV irradiation using response surface methodology (RSM). A study on the production of $\beta$-carotene by a mutant of Rhodotorula glutinis and comparison of yield of production with wild strain was carried out by Bhosale and Gadre (2001). R. glutinis was mutated by irradiation of UV and the production of $\beta$-carotene was 120 -fold higher than the parent culture. This efficient treatment is convenient and able to enhance the pigment production from bacterial strains.

Besides mutations, whole genome sequencing of the bacteria has also been carried out to understand the promising nature of pigment production. The draft genome data were analysed by Ganapathy et al. (2016) for the biosynthesis of yellow pigment from Planococcus maritimus MKU009 strain, which was isolated from surface marine water, India. The carotenoid producing genes, diapophytoene desaturase $(c r t \mathrm{~N})$, phytoene synthase $(c r t \mathrm{~B})$, phytoene desaturase $(\operatorname{crtP})$ and phytoene dehydrogenase $(\mathrm{crtI})$ were located

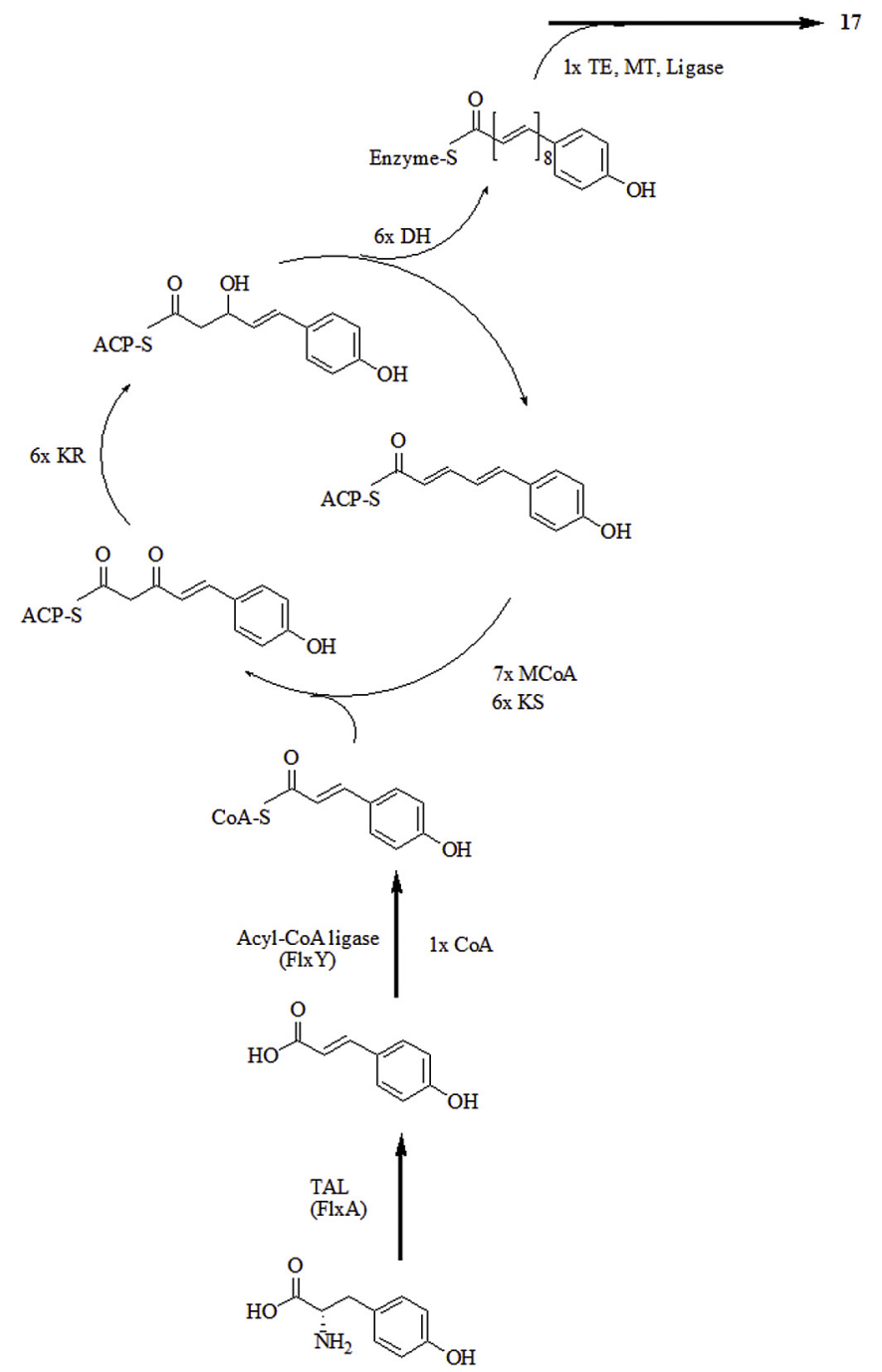

Fig. 6. Postulated biosynthesis of flexirubin in C. pinensis. AT: acyltransferase; KS: ketosynthase; ACP: acyl carrier protein; KR: ketoreductase; DH: dehydratase; MCoA: malonyl-CoA; TE: thioesterase; MT: methyltransferase (Schöner et al., 2014).

in the genome assembly. This provides insights of the functional genomics of carotenoid production and metabolic engineering for industrial applications. A complete genome sequence and transcriptomics analysis of Monascus purpureus YY-1 was reported by Yang et al. (2015) which produces yellow pigments namely monascin and ankaflavin among their secondary metabolites. This taxonomic study proves that evolution of $M$. purpureus occurs from the family Aspergillaceae, which consist of Monascus, Penicillium and Aspergillus. Identification of such genes and investigations of the promoter regulation through sequencing analysis could elucidate the molecular aspects of pigment. These advances will guide further studies of pigmented bacterial species and lay a strong foundation for the highly efficient and modifiable synthesis of useful secondary metabolites which will greatly aid such efforts in industry.

In contrast, there are reports on identifying regulators or genes that influence the synthesis of pigments in order to suppress their expression and pigment production. Derntl et al. (2016) reported on the identification of main regulator responsible for synthesis of the yellow pigment produced by Trichoderma reesei. However, the regulator is not favourable for carbohydrate active enzyme production and makes the downstream process more complicated and 
costly. Yellow pigment regulator 2 (Ypr2), second transcription factor was found to reduce the yellow pigment formation and the expression of most cluster genes, including the gene encoding the activator, yellow pigment regulator 1 (Ypr1). It is an important option to recognise the target and manipulate the secondary metabolism cluster of any biotechnologically applied microorganism for industrial purpose.

Genetic engineering for strain improvement is among the most promising researches to be conducted about yellowish-orange pigments. Engineered strains are almost not used in the present industrial production of microbial pigments and developments made up to now with Escherichia coli or Saccharomyces cerevisiae are still unsuccessful. Things seem to move these last years with works dedicated to Corynebacterium glutamicum or Yarrowia lipolytica, which sound to be more appropriate organisms. Public perception of yellowish-orange pigments produced by engineered strains has also to be carefully taken into account, even if the present large use of enzymes from engineered microbial strains is a first good indication about the market acceptability.

\section{Fermentation strategy for enhancing pigment production}

Microorganism pigments can be produced in low yields and it is not comparable with synthetic pigments economically (Nasrabadi and Razavi, 2011). In order to meet the industrial demands, various improvements to increase the pigment production yield are necessary. Other approaches were also undertaken to obtain high yield of pigments such as utilising cheaper and low cost substrates. Additional supplementations such as nitrogen or carbon sources also improve the growth and pigment production of microorganisms. Optimisation of fermentation processes is classified as an important 'strategy' to obtain high-level production of demanding pigments (Parekh et al., 2000). Although Response Surface Methodology (RSM) has gained much importance in optimising pigment production, artificial neural networks (ANN) emerged as an attractive tool for development of non-linear empirical models. Feed forward back propagation neural network (newff) is one of the most widely used ANN paradigm. It has few layers as the first layer receives weight from the input and subsequent layers receive weight from previous layer and final layer is the network output (Velu et al., 2016). However, there is no scientific report on the production of yellowish-orange pigment from microorganism using ANN.

Optimisation of medium components and fermentation conditions were carried out using RSM in attempt to increase the yield of yellowish-orange pigments. Venil et al. (2015) reported on the optimisation of yellowish-orange pigment production from Chryseobacterium artocarpi CECT 8497 using Box Behnken design and RSM analysis. Production under optimised conditions in a $50 \mathrm{~L}$ bioreactor; $11.25 \mathrm{~g} / \mathrm{L}$ of lactose, $6 \mathrm{~g} / \mathrm{L}$ of L-tryptophan and $0.65 \mathrm{~g} / \mathrm{L}$ of $\mathrm{KH}_{2} \mathrm{PO}_{4}$ increased the yield of pigment to 7.23 fold comparing to its production prior to optimisation. Optimisation of yellow pigment, $\beta$-carotene from Rhodotorula glutinis (PTCC 5256) using Box Behnken design and RSM analysis was reported by Yolmeh and Khomeiri (2016). RSM was employed to manipulate the effects of UV irradiation and sodium azide on the pigment production from $R$. glutinis and irradiation time of $36.86 \mathrm{~s}$, irradiation distance of $38.13 \mathrm{~cm}$, incubation temperature of $24.54{ }^{\circ} \mathrm{C}$ and incubation time of $90.0 \mathrm{~h}$ were found as the optimum conditions. Production of yellow pigment from Monascus anka mutant (MYM) was optimised using RSM, particularly in Plackett-Burman design. Maximum yield was obtained in submerged fermentation with supplementation of $10.3 \mathrm{~g} / \mathrm{L}$ of peptone, $11.9 \mathrm{~g} / \mathrm{L}$ of $\mathrm{NH}_{4} \mathrm{NO}_{3}$ and $4.7 \mathrm{~g} / \mathrm{L}$ of $\mathrm{KH}_{2} \mathrm{PO}_{4}$ in the medium (Zhou et al., 2009).

A different approach, immobilisation of cultures is also used to enhance cell proliferation and production of yellowish-orange pigments. Alipour et al. (2016) found that the addition of natural loofa sponge immobilised Rhodotorula rubra in cell-immobilised airlift photobioreactor considerably increased the production of yellow pigment, carotenoid. Soap stock was used as sole carbon source for the growth and pigment production of carotenoid and bioreactor performance was optimised using rotational composite design and RSM analysis where aeration rate of $0.11 \mathrm{vvm}$ and light irradiation intensity of $2517 \mathrm{Lx}$ provided an optimum condition for producing $\beta$-carotene with a specific production rate of $22.65 \mathrm{mg} /$ g cell/day. Chávez-Parga et al. (2012) optimised the production of zeaxanthin process with Flavobacterium sp. immobilised cells in fluidised bed bioreactor using orthogonal experimental design, $\mathrm{L}_{8}$. A maximum zeaxanthin production of $3.16 \mathrm{~g} / \mathrm{L}$ obtained under optimised condition where air flow of $3 \mathrm{vvm}, \mathrm{pH}$ of 7.2 and $\mathrm{NaCl}$ concentration of $4.5 \mathrm{~g} / \mathrm{L}$, which is 10 times higher than previously reported yield.

Pigment production is increased when the cells are exposed to stress conditions which may include elevated temperatures, osmotic pressures, metabolic inhibition and existence of heavy metals and so on. Yield of pigment from fermentation is increased as bacterial growth restrained due to adaption to these stress conditions (Venil et al., 2014a). According to Afshari et al. (2015), yellow pigment production and mycelial growth of Penicillium aculeatum ATCC10409 were influenced by the effect of $\mathrm{pH}$, temperature and agitation speed under submerged fermentation. The best production of yellow pigment $(1.38 \mathrm{~g} / \mathrm{L})$ was obtained at $\mathrm{pH}$ 6.5, temperature $30.8^{\circ} \mathrm{C}$ and agitation speed of $150 \mathrm{rpm}$. In contrast, the maximal biomass concentration $(11.12 \mathrm{~g} / \mathrm{L})$ was obtained at $\mathrm{pH} 8$, temperature $30.8^{\circ} \mathrm{C}$ and agitation speed of $100 \mathrm{rpm}$. Therefore, various approaches can be attempted for effective pigment production.

Alternative sources for low-cost substrates were looked into upon reducing the cost of the pigment production as it is not economical for industrial scale. Various agro-industrial residues have been used as substrate or additives for yellowish-orange pigment production which may meet the high demands of industry. Massive utilization of agro-industrial waste in fermentation provides nutrient sources for fast growth of microorganism and enhances their pigment production. Utilization of these substrates also reduces the accumulation of biomass in large quantities which may cause deterioration to environment (Panesar et al., 2015). Table 2 shows the effectiveness of using different types of agroindustrial based medium for the production of yellowish-orange pigment by microorganisms in submerged and solid-state fermentation. Liquid pineapple waste is observed to be a suitable source of carbon and nitrogen for yellowish-orange pigment production by Chryseobacterium artocarpi CECT 8497, thereby substituting nutrient broth (Aruldass et al., 2016). Fruit wastes, derived from orange, pomegranate and pineapple can be used as a culture medium for $\beta$-carotene production from Rhodotorula rubra (Korumilli and Mishra, 2014a).

Besides growth medium, there are various factors may affect yellowish-orange pigment production by microorganisms. Development of a controlled bioprocess for enhanced pigment production may be successful upon understanding the effects of such factors and regulation of biosynthetic pathways of pigment production, thus opening the new avenues for further research in this field (Bhat et al., 2013). Fermentation technique does not seem to be a major drawback, a major problem, for the future yellowishorange pigment industry. Present industrial productions of microbial pigments were easily scaled-up from lab bench to multimetric-tons fermentation. One critical point could be the migration of solid-state fungal pigmented cultures to liquid ones as metabolites that are produced in both cases are not always the 
Table 2

Different types of agro-industrial based medium for yellowish-orange pigment production.

\begin{tabular}{|c|c|c|c|c|}
\hline Strain & Pigment & Substrate & Condition & Reference \\
\hline $\begin{array}{l}\text { Chryseobacterium artocarpi } \\
\text { CECT } 8497\end{array}$ & $\begin{array}{l}\text { Yellowish-orange/ } \\
\text { Flexirubin }\end{array}$ & Liquid pineapple waste & $\begin{array}{l}30^{\circ} \mathrm{C} ; 200 \mathrm{rpm} ; 24 \mathrm{~h} ; 50 \mathrm{~L} \\
\text { bioreactor }\end{array}$ & Aruldass et al., 2016 \\
\hline Sporidiobolus pararoseus & Orange $/ \beta$-carotene & $\begin{array}{l}\text { Agricultural substrate (Glycerol, corn steep liquor and } \\
\text { parboiled rice water) }\end{array}$ & $25^{\circ} \mathrm{C} ; 180 \mathrm{rpm} ; 120 \mathrm{~h}$ & Valduga et al., 2014 \\
\hline Rhodotorula rubra & $\begin{array}{l}\text { Yellowish-orange } / \beta \text { - } \\
\text { carotene }\end{array}$ & Fruit waste (pineapple, pomegranate and orange) & $28.2^{\circ} \mathrm{C} ; 150 \mathrm{rpm} ; \mathrm{pH} 7.0$ & $\begin{array}{l}\text { Korumilli and Mishra, } \\
\text { 2014a }\end{array}$ \\
\hline Bacillus clausii & $\begin{array}{l}\text { Yellowish-orange } / \beta \text { - } \\
\text { carotene }\end{array}$ & Rice powder & $35^{\circ} \mathrm{C} ; \mathrm{pH} 7.0$ & $\begin{array}{l}\text { Korumilli and Mishra, } \\
\text { 2014b }\end{array}$ \\
\hline Lactobacillus plantarum & Yellow/carotenoid & Palm date waste & $30^{\circ} \mathrm{C} ; \mathrm{pH} 7.0 ; 96 \mathrm{~h}$ & Elsanhoty et al., 2012 \\
\hline Sarcina sp. & Yellow/Carotenoid & Apple pomace & $35^{\circ} \mathrm{C} ; \mathrm{pH} 5.5 ; 72 \mathrm{~h}$ & Joshi et al., 2011 \\
\hline Rhodotorula glutinis MT-5 & $\begin{array}{l}\text { Yellowish-orange } / \beta \text { - } \\
\text { carotene }\end{array}$ & Waste loquat kernels & $30^{\circ} \mathrm{C} ; 200 \mathrm{rpm} ; 120 \mathrm{~h}$ & Taskin and Erdal, 2011 \\
\hline
\end{tabular}

same.

\section{Processing techniques}

Production of yellowish-orange pigments can be extracellular or intracellular depending on the microorganisms. Numerous methods have been reported to improve the pigment extraction and purification efficiency. Cell disruption method using ultrasonication is reported by Venil et al. (2015) and Aruldass et al. (2016) to extract yellowish-orange pigment, flexirubin from pellet of Chryseobacterium artocarpi CECT 8497 using acetone as the pigment being produced intracellularly. Vacuum liquid chromatography and preparative thin layer chromatography techniques were used to isolate flexirubin from yellowish-orange pigment. Kamarudin et al. (2013) extracted intracellular yellow pigment from pellet of Staphylococcus kloosii using methanol. Yongsmith et al. (2013) used ethanol and hot water bath extraction method to extract yellow pigment from mutant Monascus sp. TISTR 3179 fermented in ground brown rice. Two new yellow compounds, monascusones $\mathrm{A}$ and $\mathrm{B}$, together with two known yellow compounds, monascin and FK17-P2b2 were isolated using Sepdhadex LH-20 and silica gel chromatography techniques. Yet, it is still necessary to improve the separation and purification of yellowishorange pigments from culture using various technological advances for easier and time saving extraction to reach the maximum possible yield, purity and reduce the energy and intensive process.

The future of microbial pigment processing relies on the use of green solvents for extraction. Several solvents that can be used in extraction processes may be named "green solvents". Undoubtedly, water and carbon dioxide, two innocuous and renewable solvents which are well known may be included to this group. The most popular solvent applied in extraction processes is water. Moreover, due to the possibility of changing the physicochemical properties of water with temperature and pressure, the applications of water are even more expanded, for instance in subcritical extraction processes of less polar compounds. Carbon dioxide is also commonly applied under supercritical conditions in extraction processes. Wide application of carbon dioxide as a supercritical fluid results mainly from its advantageous supercritical temperature and pressure conditions $\left(31^{\circ} \mathrm{C}\right.$ and $73.8 \mathrm{bar}$ ), its economy and environmental friendliness. Another class of green solvents is ionic liquids (ILs) which attracted growing interest due to their unique physicochemical properties.

\section{Industrial production of yellowish-orange pigment (lab scale-pilot scale)}

Biotechnological process plays a main role in providing high yields of pigments with low cost and less waste disposal (Venil et al., 2014a). Upon cultivating microorganism in large scale, various factors such as bioreactor design, substrates used as growth medium, microorganisms and type of fermentation (batch, fedbatch or continuous) must be taken into consideration to design a sustainable process for yellowish-orange pigment production. Several parameters are needed to be optimised in bioreactor such as temperature, agitation, aeration, $\mathrm{pH}$ and dissolved oxygen among others to reach the desired productivity of microbial pigment. Fig. 7 shows the scale-up of Chryseobacterium artocartpi CECT 8497 from lab scale to industrial fementer in liquid pineapple waste. Besides submerged fermentation, solid-state fermentation is an additional approach to increase the yield of pigment.

Recently, Aruldass et al. (2016) reported that flexirubin is produced by Chryseobacterium artocarpi CECT 8497 using liquid pineapple waste as a low cost medium in a 5 and $50 \mathrm{~L}$ stirred-tank bioreactor with yield of $540 \mathrm{mg} / \mathrm{L}$ and $200 \mathrm{mg} / \mathrm{L}$, respectively. In stir-tanked bioreactor, C. artocarpi CECT 8497consumed oxygen that is transferred in the region of impeller and it diffuses from culture medium into a flow of inert gas. The growth of bacteria promoted and initiated flexirubin-type, yellowish-orange pigment production. Alipour et al. (2016) used a novel approach by fermenting Rhodotorula rubra in cell-immobilised airlift photobioreactor where soap stock plays a role as sole carbon source to enhance the carotenoid, orange pigment production. The loofa sponge from matured dried fruit of Luffa cylindrica was used as a packing material in the downcommer section of bioreactor. Open pore structures of loofa sponge provide a proper condition of cell growth, biomass and immobilised cells could grow on the new nutrients medium discharged. This airlift bioreactor provides stable conditions for carotenoid production by freely suspended cells and no limitation for mixing in bioreactor as the loofa sponge has open pore structure.

Natural yellow carotenoid, lutein production was carried out in $1 \mathrm{~L}$ photobioreactor using microalga Scenedesmus obliquus FSP-3 (Ho et al., 2015). The microalga was cultivated at $28^{\circ} \mathrm{C}, \mathrm{pH} 6.0$ and agitation rate of $300 \mathrm{rpm}$ with continuous feeding of $2.5 \% \mathrm{CO}_{2}$ as sole carbon source for 6-10 days. Highest yield of lutein, $6.01 \mathrm{mg} / \mathrm{L} /$ day and biomass of $1304.8 \mathrm{mg} / \mathrm{L} /$ day were obtained using semi-continuous strategy with supplementation of $8 \mathrm{mM}$ calcium nitrate, continuous light supply and $10 \%$ of medium replacement. A different approach, fed-batch fermentation for yellow pigment production from Monascus sp. was carried out by Krairak et al. (2000) in a $5 \mathrm{~L}$ bioreactor to overcome the glucose depletion during fermentation. Pigment production from Monascus started after the glucose concentration reduced to a low level and cell growth nearly stopped. The cultivation was performed at the agitation rate of $600 \mathrm{rpm}$, aeration at $0.75 \mathrm{vvm}$, initial $\mathrm{pH}$ at 6.5 and temperature at $28^{\circ} \mathrm{C}$. Initial concentration of glucose, $10 \mathrm{~g} / \mathrm{L}$ gave the maximum production of yellow pigment of $1015 \mathrm{U} / \mathrm{mL}$ when 


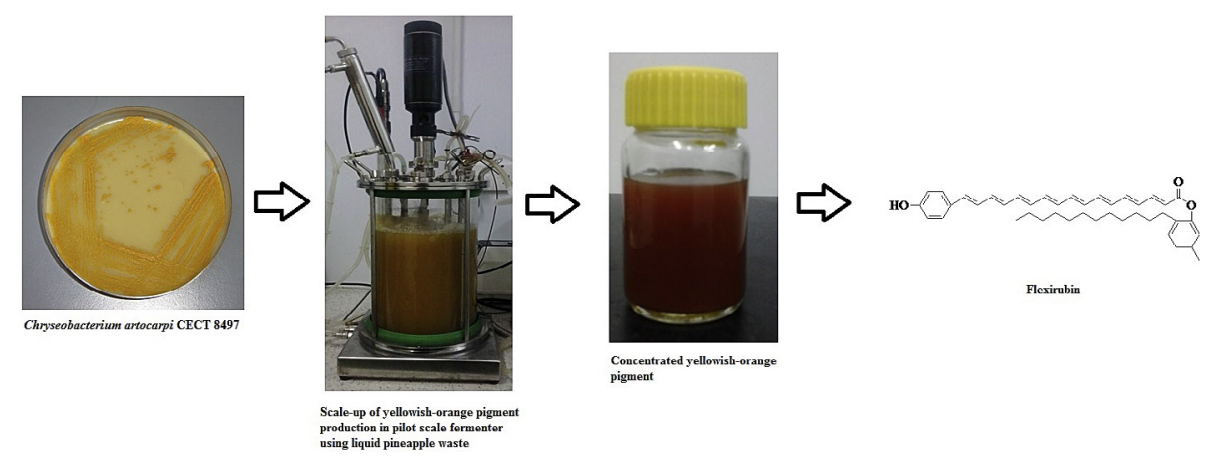

Fig. 7. Pilot scale yellowish-orange pigment production in liquid pineapple waste medium.

the $\mu$ (specific growth rate) was controlled at $0.01 / \mathrm{h}$. Based on previous reports on large scale production of yellowish-orange pigment, suitable culture system design with proper bioreactor for industrial fermentation is needed to produce high pigment production to meet the demand of industry.

\section{Pharmacological properties of yellowish-orange pigments}

Yellowish-orange pigments are studied for their biological potential and recently attracted the interest of the scientific community and, as a consequence, significantly increasing the number of studies in the literature. These pigments exhibit several interesting biological activities with clinical relevance, some of which have already been previously reviewed (Kumar et al., 2015). These reports call attention to a still yet to be studied yellowish-orange pigments activities, which will uncover new knowledge on their role in ecological environments. Researchers have highlighted the clinical importance of these pigments, including antibacterial, antioxidant, anti-tumoral, anti-inflammatory, anti-lipid activities, most of which have not been previously reviewed. In line with that, mechanism of action of the reported biological activities is still on the investigation. Current new features of these yellowish-orange secondary metabolites as chemotherapeutic agents are discussed.

\subsection{Antimicrobial activities}

A soluble yellow-orange pigment from Streptomyces sp. D25 reported to possess antibacterial activity with inhibition zone ranged from 15 to $20 \mathrm{~mm}$ against Staphylococcus sp., Lactobacillus sp., Alcaligens sp., Pseudomonas sp. and Bacillus sp. at $25 \mu \mathrm{g} / \mathrm{mL}$ in disc diffusion method (Radhakrishnan et al., 2016). Mohana et al. (2013) reported that yellow carotenoid from Micrococcus luteus demonstrated inhibitory action against Staphylococcus aureus and Streptococcus faecalis with wide inhibition zones at the concentration ranged from 2 to $10 \mathrm{mg} / \mathrm{mL}$. Similarly, Umadevi and Krishnaveni (2013) reported that yellow pigment produced by Micrococcus luetus, isolated from marine water showed antibacterial action with wide inhibition zones against Staphylococcus sp., Klebsiella sp. and Pseudomonas sp. In vitro studies demonstrated yellow pigment, class of flexirubin from Flavobacterium sp. Ant342 (F-YOP) possessed antimycobacterial activity upon inhibiting Mycobacterium smegmatis $\mathrm{mc}^{2} 155$, avirulent Mycobacterium tuberculosis $\mathrm{mc}^{2} 6230$ and virulent Mycobacterium tuberculosis $\mathrm{H}_{37} \mathrm{RV}$ with minimum inhibitory concentration of $3.6 \mu \mathrm{g} / \mathrm{mL}, 2.6 \mu \mathrm{g} / \mathrm{mL}$ and $10.8 \mu \mathrm{g} / \mathrm{mL}$, respectively (Mojib et al., 2010). Alamar Blue Assay (MABA) and Nitrate Reductase Assay were used to determine the antimycobacterial activity of the yellow pigment.

\subsection{Anti-tumoral activities}

Flexirubin mediated silver nanoparticles synthesised from Chyrseobacterium artocarpi CECT 8497 showed anticancer activity against human breast cancer cells, MCF-7 with a low $\mathrm{IC}_{50}$ value of $36 \mu \mathrm{g} / \mathrm{mL}$ via apoptosis. Combination of silver and flexirubin as nanoparticles exert synergistic cytotoxic effect on cancer cells by entering into the cells or nucleus and causing higher cell death (Venil et al., 2016a). Prashanti et al. (2015) employed various approaches to study anticancer activity of yellow pigment produced by Streptomyces griseoaurantiacus JUAC T01 against cervical cancer (HeLa) and liver cancer (HepG2) cells. Low $\mathrm{IC}_{50}$ values of 1.5 and $1.8 \mu \mathrm{g} / \mathrm{mL}$ were obtained for HeLa and HepG2 cells, respectively with decrease in the number of viable cells, presence of apoptotic bodies, nuclear condensation and sheared DNA distinctly observed in pigment treated cancer cells.

Hsu et al. (2011) reported on anticancer activity of two yellow compounds, monaphilone A and ankaflavin isolated from Monascus purpuresus NTU 568 against human laryngeal carcinoma (Hep-2) cells. Both compounds may induce major apoptosis through the caspase-9-mediated intrinsic pathway and minor through caspase8-mediated extrinsic pathway. Yellow pigment, ankaflavin from Monascus sp. possessed anticancer activity against human lung cancer (A549) and liver cancer (HepG2) cells with an $\mathrm{IC}_{50}$ value of $15 \mu \mathrm{g} / \mathrm{mL}$ while it posed no significant toxicity to normal human lung fibroblast (MRC-5 and WI-38) cells at the same concentration. Ankaflavin attribute anticancer activity via apoptosis due to chormosomal condensation and fragmentation as significant sub-G1 peak was observed in flow cytometry (Su et al., 2005).

\subsection{Antioxidant activities}

Yellow-orange pigment from Streptomyces sp. D25, isolated from soil of desert showed strong antioxidant activity in DPPH and nitric oxide assay with maximum of $35.63 \%$ and $96.19 \%$ of free radical scavenging activities, respectively. Although nitric oxide has been involved in several biological functions, such as antimicrobial, neurotransmission, antitumor and vascular homeostasis activities, it causes oxidative damage. Nitric oxide may react with superoxide to perform peroxy nitrite anion, a potential oxidant that can decompose to produce hydroxide $(\mathrm{OH})$ and nitric oxide (Radhakrishnan et al., 2016). Microencapsulated flexirubin produced from Chryseobacterium artocarpi CECT 8497 reported to have radical scavenging activity in 2,2-diphenyl-1-picryl-hydrazyl-hydrate (DPPH) assay with highest value of $687.5 \mathrm{~g} / \mathrm{kg}$ wet basis. Encapsulated flexirubin showed good protection against oxidation which attributed to amphiphilic properties of the phenol constituents of flexirubin (Venil et al., 2016b).

Hydrogen-atom transfer (HAT) mechanism is reported to occur 
in any phenolic antioxidant compounds (Craft et al., 2012). Thus, similar mechanism may occur in flexirubin compound (16) by quenching free radicals species upon donating hydrogen atom to become a more stable free-radical species. The more stable flexirubin species is less likely to propagate further radical reactions with initiation substrates. The proposed illustration (Fig. 8) shows the two sequential hydrogen abstractions incurred by peroxyl radicals resulting in the conversion of flexirubin and resultant creation of two hydroperoxides. Two hydroxyl functional groups located on benzene rings which render it sufficiently stable to participate in free radical redox chemistry. The generated phenoxyl radicals of flexirubin compound could form dimer or can react with each with substrate-radical initiator forming oxidised complex.

\subsection{Anti-lipid activities}

Yellow pigments from fungi were mostly studied in various aspects and Lee et al. (2013b) reported on the anti-obesity effect of the ankaflavin and monascin isolated from Monascus purpuresus NTU-568. Both pigments strongly inhibited differentiation and lipogenesis by inhibiting the enhancer-binding protein $\beta$ (C/EBP $\beta$ ) expression, downstream peroxisome proliferator-activated receptor $\gamma$ and enhancer-binding protein $\alpha(\mathrm{C} / \mathrm{EBP} \alpha)$ expressions.
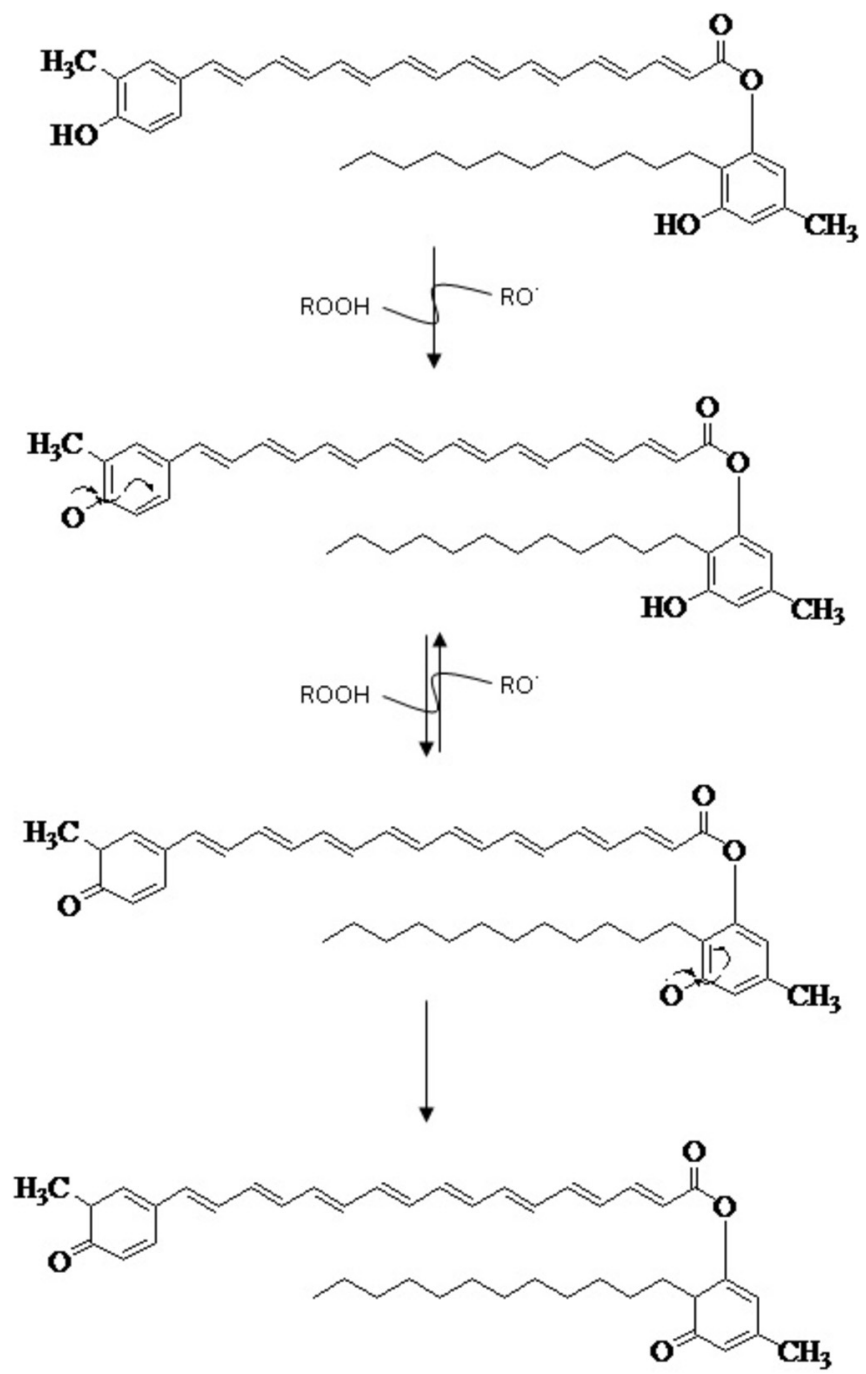

Fig. 8. Proposed HAT conversion of flexirubin compound.
Ankaflavin and monascin were reported as the first agents to suppress Niemann-Pivk C1 like 1 (NPC1L1) protein expression associated with small intestine tissue absorption. In previous study, Lee et al. (2010) reported that ankaflavin and monascin acted as novel hypolipidemic and high-density lipoprotein cholesterol raising agent. They were able to reduce the cholesterol, triglyceride and low-density lipoprotein cholesterol level in serum and aorta lipid plaque. Similar report on ankaflavin and monascin act as anticholesterol agent was demonstrated by Jou et al. (2010) where they were able to prevent the differentiation of preadipocytes and accumulation of lipid upon stimulation of basal lipolysis of mature adipocytes.

\subsection{Anti-inflammatory and anti-allergic activities}

Ankaflavin and monaphilone A also inhibited inflammatory responses in murine macrophage RAW 264.7 cells by inhibiting inducible nitric oxide synthase (iNOS). Some of nitric oxide (NO)mediated responses like NO-stimulated cyclooxygenase (COX)-2 expressions were reduced through p38-dependent pathway or blockage of cell-deactivation of COX-2 (Hsu et al., 2011). Ankaflavin also reported to possess anti-allergic activity by elevating nuclear factor (Nrf)-2 protein translocation in both lung cell line (A549) and lungs ovalbumin (OVA)-challenged mice. Allergen-driven airway inflammation reduced as the mRNA expression of antioxidant enzymes regulated by Nrf- 2 increased. This was the first study to illustrate that ankaflavin act as a novel Nrf-2 activator for modulating the oxidative stress pathway to improve the lung injury and ameliorate the development of airwar inflammation (Hsu et al., 2012).

\section{Market potential for pigment production}

The markets for natural colourants are on rise in the economically fast-growing countries all over the world due to globalisation of research trends and healthier lifestyle. Synthetic colourants mostly continue to be used by food processing and cosmetic industries but various synthetic colourants are banned due to their hyperallerginicity, carcinogenicity and other toxicological problems (Tuli et al., 2014). These adverse effects have made inclination towards exploiting bacterial pigments for various colouring purposes, like food, textiles, painting, cosmetics, pharmaceuticals, plastics and more. It was reported that $\beta$-carotene, yellowish-orange pigment produced by bacteria has an approximate cost of US $\$ 1000 / \mathrm{kg}$ against US $\$ 500 / \mathrm{kg}$ by synthetic colourant. Pigments produced by microorganism are natural even though they are costly and compete in the market segments (Venil et al., 2013).

Generally, there are significant growths in demands of natural pigments due to improvements seen in technology and industrial sectors. The worldwide organic colourants market share is reported to increase from $4.9 \%$ in 2003 to $\$ 10.6$ billion in 2008 as the global market for food colourant was approximately $\$ 1.55$ billion in 2011 (Pankaj and Kumar, 2014). Currently, the cost of pigments production from microorganisms is higher than synthetic colourants yet this can be overcome by using low cost substrates for fermentation and mass biotechnical production of the pigments (Pankaj and Kumar, 2014). These pigments were expected to dominate the organic market in near future due to their environmental acceptability and superior performances (Venil et al., 2014a).

Following these statements, authors emphasise that markets at a world level are never covered by a single source of colourant. Many sources (chemical nature-identical or artificial colourants, plant sources, insects, microorganisms) compete every day in many sectors of the industry, some sources disappear, some collapse, others appear. Prices and consumer preferences drive this 
permanent adjustment.

\section{Potential industrial applications of yellowish-orange pigments}

Pigments produced by microorganism are subjected to intense research due to their potential diverse applications. Although various natural pigments are produced by microorganism, researches focused on yellow pigment, such as xanthomonadin from Xanthomonas campestris pv (Poplawsky et al., 2000), monascin and ankaflavin from Monascus sp (Lee et al., 2013a, 2013b). However, studies on yellowish-orange, flexirubin-type pigments are limited, because only several microorganisms produce these pigments. The research concerning flexirubin has mainly focused on isolation of pigment producing microorganism and optimisation of pigment production. In addition to its biological activity as antioxidant activity, flexirubin has also exhibit anticancer activity in human breast cancer (Venil et al., 2016a, 2016b).

Recently, these yellow pigments from microorganism have been used as additives or supplements in the food industries, cosmetics, pharmaceuticals, livestocks feed and other applications (Kirti et al., 2014) (Fig. 9). In response to demand of natural pigments as natural substance in dyeing industries, healthy functional foods, cosmetic products for human health and safety have been consistently increased (Venil et al., 2013).

\subsection{Application as food colourants}

Riboflavin (vitamin $\mathrm{B}_{2}$ ), a yellow food colourant produced by microorganisms such as fungi Eremothecium ashbyii or Ashbya gossypi and yeast Candida guilliermundii or Debaryomyces subglobosus was used in many applications including dressing, sherbet, beverage instant desserts, ice-creams, tablets and other products. However, the uses in cereal based products are limited due to its slight odour and naturally bitter taste (Jacobson and Wasileski, 1994). Zeaxanthin derived from Flavobacterium sp. is used as an additive in poultry feeds to strengthen the yellow colour of the skin of animals or accentuate the colour of the yolk of their eggs

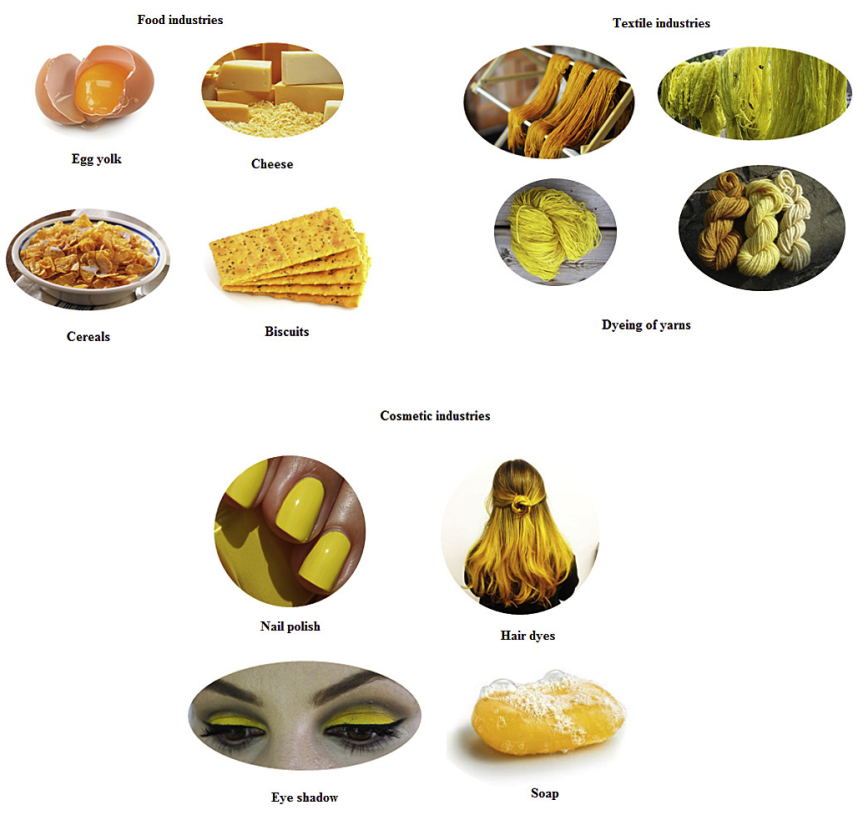

Fig. 9. Utilization of yellowish-orange pigments in food, textile and cosmetic industries.
(Alcantara and Sanchez, 1999). Fish and crustaceans, such as shrimps and carp convert zeaxanthin to red-coloured pigment, astaxanthin which enhanced desirable red colouration of the shells (Sajilata et al., 2008). These pigments are considered safe and approved by FDA and will not only benefit human health but also preserve the biodiversity, as toxic chemicals released into environments while production of synthetic colourants could be restricted (Neeraj et al., 2011).

\subsection{Application in pharmaceutical industry}

Most studies showed that monascin and ankaflavin derived from Monascus sp. have the efficacy and potential clinical applications in treating several diseases. Other yellowish-orange pigments also have certain properties like antibiotic, anticancer and immunosuppressive properties. Numerous biological effects such as inhibition of non-alcoholic fatty liver, amelioration of pancreatic damage and hyperglycemia in patients with diabetes, antioxidant and anti-inflammatory activities of monascin and ankaflavin were reported. Considering the health benefits of these two compounds, clinical trials of ANKASCIN 568 plus (Monascus purpureus NTU 568 fermented product) was conducted in Taiwan and reported that it may be a potential agent to regulate blood glucose, blood lipids and treat coronary artery diseases. A significant reduction of serum blood glucose, total cholesterol and low density level cholesterol levels were observed in patients upon administrated with two capsules (500 mg/capsule) of ANKASCIN 568 plus daily for more than 6 weeks (Wang et al., 2017).

Chen et al. (2016) reported ANKASCIN 568 plus may be an option in future Alzheimer's disease (AD) as it has the ability to suppress free radical generation, activate the antioxidant enzymes, simultaneously reduce oxidative stress and ameliorate AD pathology. These effects protected the tested rats against aluminiuminduced memory and learning deficits. ANKASCIN 568 plus showed neuroprotection mechanisms, including reduction of acetycholinesterase $A \beta_{1-40}, A \beta_{1-42}$ and phosphorylated tau levels in hippocampus, inhibition of the amyeloid precursor protein (APP) synthesis and inhibition of $A \beta$-induced oxidative response. Besides ankaflavin and monascin, neurotransmitter $\gamma$-aminobutyric acid (GABA) a metabolite of ANKASCIN 568 plus may help to improve memory and learning ability in the behaviour test of rats.

\subsection{Application in textile and leather industry}

Poorniammal et al. (2013) reported on the application of yellow pigment extracted from fungi Thermomyces sp. on various fabrics, namely cotton, silk and wool. The pigment shows high affinity to silk fabrics with good light fastness, colour fastness to washing and colour fastness to rubbing. Optimum colour intensity was observed at $30^{\circ} \mathrm{C}, \mathrm{pH} 3$ with Myrobalan as a mordant in 20 min duration. Additionally, silk dyed with the yellow pigment was found to exhibit $51.05 \%$ antibacterial activity against Salmonella typhi. Considering its antibacterial activity, the pigment can be used for specific product development in medical applications like face mask, bandage, wound bandage, wound dressing, suture threads and others.

Ahmad et al. (2012) observed the application of yellow pigment from Chryseobacterium sp. on natural silk, Dubai silk, linen, Japanese cotton and Indian cotton by immersion of fabrics in the pigment solution at $80-90^{\circ} \mathrm{C}$ and optimum colour intensity was observed after $60 \mathrm{~min}$. Velmurugan et al. (2010) showed dyeing potential of pigments from five different fungi, including yellow pigment from Penicillum spp. for pre tanned leather samples. Optimum uptake of pigment, pigment penetration and intensity of colour was observed at $70^{\circ} \mathrm{C}, \mathrm{pH} 5$ and pigment concentration $6 \%$ 
on weight of leather (owl). The leather was uniformly dyed with intense and bright shade colour of pigment. However, strength characteristics and organoleptic properties of the dyed leathers were not significantly altered. This indicates that yellow pigment from fungus can be used as natural colourant for leather dyeing.

Han and Yang (2005) reported that curcumin had high affinity to wool and its mechanism is due to the ionic and van der Waals attractions between them. As curcumin had weak acidity due to hydroxyl group, the electrons were easily transferred to other parts of the molecules. The dissociation of hydrogen ions have provided negative charges to curcumin and initially caused ionic attraction to positively charged amine groups of wool protein under acidic dyeing conditions. The presence of van der Waals forces between curcumin and wool were mainly due to the existence dipoles, induced dipoles and $\pi-\pi$ interactions among the conjugated systems between them.

Mordant was found to be vital for most of the natural dyes or pigments in order to set permanently in any fiber. Metal ions can be used as mordants since they were able to act as electron acceptors from electron donors to form coordination bonds with dye molecules and making them insoluble in water (Böhmer, 2002). Thus, the uptake and retention of natural dyes are improved, which results in better shades and colour fastness properties on the fibers. Alum, chrome, stannous chloride, copper sulphate, ferrous sulphate and other metal ions are common mordants used in textile industries (Kulkarni et al., 2011). Although various natural pigments have been studied for textile dyeing, no reports on the possible complex formation of flexirubin pigment with metal ions mordant and fiber has been described. Yellowish-orange colour of flexirubin may change in shades or drastically altered as complex formation between metal ions mordant with pigment and fiber were able to steer colour of dye mordant solution in a wider range.

The possible structures of complexes with flexirubin pigment

A
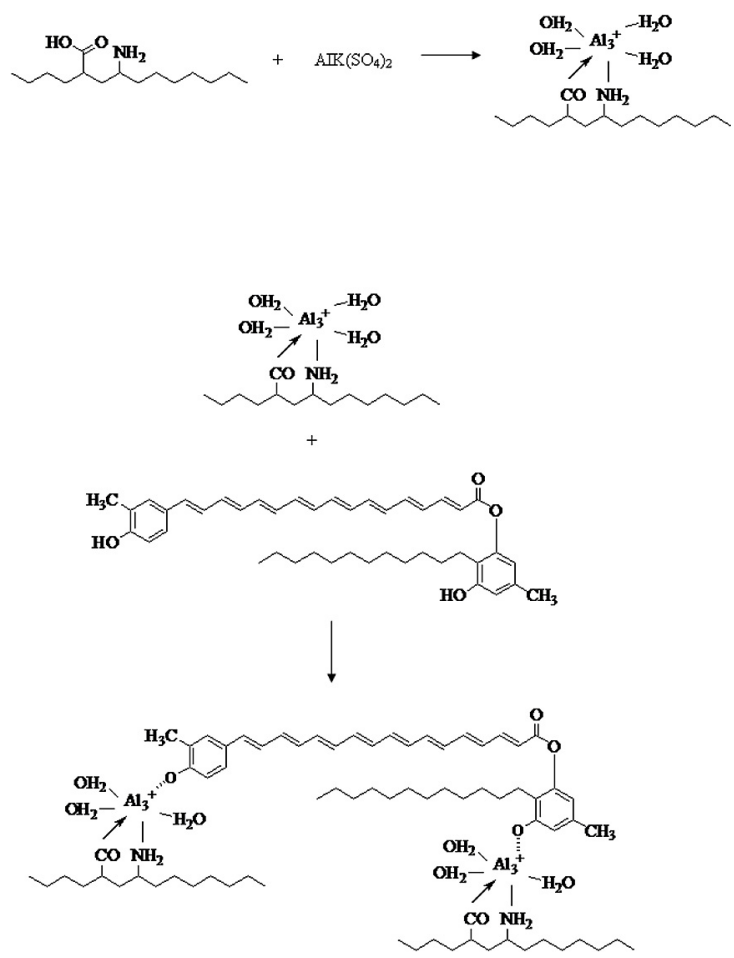

Fig. 10. Complex formation between the functional groups of wool and the aluminium cation at pre-mordanting process (A) Proposed complex formation between flexirubinaluminium-wool (Adopted from Mazeyar, 2009) (B). and aluminium in premordanting of wool or ferrous sulphate of silk were shown in Figs. 10 and 11. Metal ions form coordination complex with the electron donor functional group $(\mathrm{OH})$ of flexirubin and with functional groups of wool proteins $\left(\mathrm{NH}_{2}, \mathrm{COOH}\right)$ and silk $\left(\mathrm{NH}_{2}, \mathrm{CO}\right)$. This will provide a bridge between the pigment and the wool or silk. Thus, the wash fastness properties of samples will be improved by the flexirubin-metal-fiber complexes.

\subsection{Application in cosmetics}

A patent (US6740313 B2) was reported by Forestier et al. (2004) where ankaflavin, one of the major pigment isolated from Monascus sp. was used as a dermatological composition to produce a long lasting and non-covering colouration skin that is similar to natural tan. Dihydroxyacetone (DHA) is commonly used in cosmetic as an agent for artificially tanning the skin but the length of time the colouration develop is longer. Ankaflavin was used to replace DHA in the composition which consist of pigment, absolute ethanol, propylene glycol, demineralised water and an organic agent for screening out UV radiation, terephthalylidenedicamphorsulphonic acid. These compositions according to the formulation showed immediate colouration of good intensity on Vitroskin test. Most of the applications of yellowish pigment in industries are derived from fungi, namely Monascus sp. In fact, detailed work on yellow pigments from bacteria, such as flexirubin needs to be intensified to suit its various industrial needs.

Previous paragraphs clearly illustrate the broad range of applications were microbial yellowish-orange pigments demonstrated strong capacities. We are still in the infancy of the development of this industrial sector, which is hugely younger that the markets of antibiotics or enzymes as examples. For full efficiency, academics and companies staffs should work hand in hand during the next decade.

\section{Future perspectives}

Yellowish-orange pigments from various microorganisms have

A

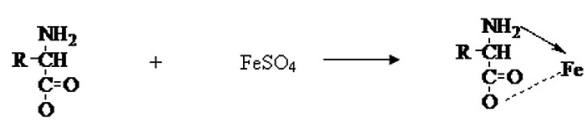

B
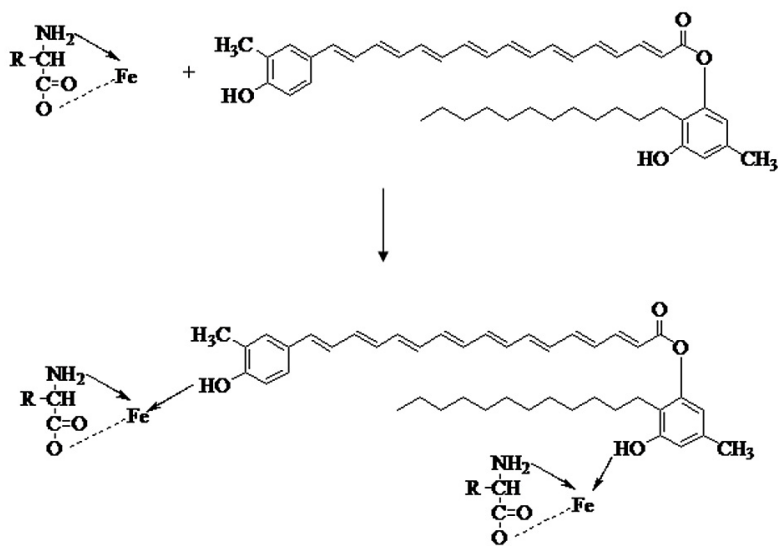

Fig. 11. Proposed complex formation between the functional groups of silk and the ferrous sulphate at pre-mordanting process (A) Proposed complex formation between flexirubin-ferum-silk (Adopted from Uddin, 2014) (B). 
great economic potential, industrial importance which offers various applications, including textile, food, pharmaceuticals and cosmetics. Most of the yellowish-orange pigments that are being studied extensively are derived from fungi. Considering the recent awareness of utilization of natural colourants, the production of pigments still could not meet the demand of industries. Various steps are being addressed to understand and explore in depth the nature, characteristic and potential of yellowish-orange pigments. Yellowish-orange pigments from other sources than fungi, including bacteria, alga and microalgae should be screened and studied intensively. The function and regulation of synthesis of specific yellowish-orange pigment under controlled environmental conditions are needed to be investigated. The biosynthesis pathways of yellowish-orange pigment from various microorganisms are waiting to be postulated. Various strategies to modify or alter the biosynthetic pathway for drug discovery and other important applications of pigments are needed to be exploited. Developing low cost fermentation using substrates from renewable sources for less expensive process of pigment production may be economical for industrial demands and biotechnology may play a crucial role for large scale fermentation. The annual market volumes for natural colours are expected to increase up to 89.9 metric ton. Thus, these yellowish-orange pigments are worth for variety of applications, providing fascinating platform for future research.

\section{Compliance with ethical standards}

Conflict of interest The authors declare that they have no conflict of interest.

\section{Acknowledgement}

This research was financially supported by the Research University grants (Q.J130000.21A2.03E40 and Q.J130000.2526.12H64).

\section{References}

Achenbach, H., Böttger, A., Kohl, W., Reichenbach, H., 1979. Untersuchungen zur biogenese des flexirubins-herkunft des benzolringes a und der aromatischen C-methylgruppen. Phytochem 18 (6), 961-963.

Achenbach, H., Kohl, W., Wachter, W., Reichenbach, H., 1978. New flexirubin-type pigments. Arch. Microbiol. 117, 253-257.

Afshari, M., Shahidi, F., Mortazavi, S.A., Tabatabai, F., Eśhaghi, Z., 2015. Investigating the influence of $\mathrm{pH}$, temperature and agitation speed on yellow pigment production by Penicillium aculeatum ATCC 10409. Nat. Prod. Res. 29 (14), 1300-1306.

Ahmad, W.A., Ahmad, W.Y.W., Zakaria, Z.A., Yusof, N.Z., 2012. Application of Bacterial Pigments as Colorant. The Malaysian Perspective. Springer Briefs in Molecular Science. Springer, pp. 57-74.

Aksu, Z., Eren, A.T., 2007. Production of carotenoids by the isolated yeast of Rhodotorula glutinis. Biochem. Eng. J. 35 (2), 107-113.

Alcantara, S., Sanchez, S., 1999. Influence of carbon and nitrogen sources on Flavobacterium growth and zeaxanthin biosynthesis. J. Ind. Microbiol. Biotechnol. 23, 697-700.

Alipour, S., Habibi, A., Taavoni, S., Varmira, K., 2016. B-carotene production from soap stock by loofa-immobilized Rhodotorula rubra in an airlift photobioreactor. Process Biochem. 54, 9-19.

Amin, K.A., Hameid, H.A., Elsttar, A.H.A., 2010. Effect of food azo dyes tartrazine and carmoisine on biochemical parameters related to renal, hepatic function and oxidative stress biomarkers in young male rats. Food Chem. Toxicol. 48, 2994-2999.

Aruldass, C.A., Aziz, A., Venil, C.K., Khasim, A.R., Ahmad, W.A., 2016. Utilization of agro-industrial waste for the production of yellowish orange pigment from Chryseobacteirum artocarpi CECT 8497. Int. Biodeter. Biodegrad. 113, 342-349.

Awan, M.S., Tabbasam, N., Ayub, N., Babar, M.E., Rana, S.M., Rajoka, M.I., 2011. Gamma radiation induced mutagenesis in Aspergillus niger to enhance its microbial fermentation activity for industrial enzyme production. Mol. Biol. Rep. 38, $1367-1374$.

Berman, J., Zorrilla-López, U., Farré, G., Zhu, C., Sandmann, G., Twyman, R.M., Capell, T., Christou, P., 2015. Nutritionally important carotenoids as consumer products. Phytochem. Rev. 14, 727-743.

Bhat, S.V., Khan, S.S., Amin, T., 2013. Isolation and characterization of pigment producing bacteria from various foods for their possible use as biocolors. Int. J.
Recent. Sci. Res. 4, 1605-1609.

Bhosale, P.B., Gadre, P., 2001. Production of $\beta$-carotene by a mutant of Rhodotoruld glutinis. Appl. Microbiol. Biotechnol. 55, 423-427.

Böhmer, H., 2002. Koekboya: Natural Dyes and Textiles: a Colour Journey from Turkey to India and beyond. Remhöb Verlag, Germany.

Cardoso, L.A.D.C., Kanno, K.Y.F., Karp, S.G., 2017. Microbial production of carotenoids-a review. Afr. J. Biotechnol. 16 (4), 139-146.

Chávez-Parga, M.D.C., Munguía-Franco, A., Anguilar-Torres, M., EscamillaSilva, E.M., 2012. Optimization of Zeaxanthin production by immobilized Flavobacterium sp. cells in fluidized bed bioreactor. Adv. Microbiol. 2, 598-604.

Chen, C.L., Chang, K.Y., Pan, T.M., 2016. Monascus purpureus NTU 568 fermented product improves memory and learning ability in rates with aluminiuminduced Alzheimer's disease. J. Func. Food 21, 167-177.

Chen, W.M., Huang, W.C., Young, C.C., Sheu, S.Y., 2013. Flavobacterium tilapiae sp. nov., isolated from a freshwater pond, and emended descriptions of Flavobacterium defluvii and Flavobacterium johnsoniae. Int. J. Syst. Evol. Microbiol. 63, 827-834.

Craft, B.D., Kerrihard, A.L., Amarowicz, R., Pegg, R.B., 2012. Phenol-based antioxidants and the in vitro methods used for their assessment. Compr. Rev. Food Sci. Food Saf. 11, 148-173.

Derntl, C., Rassinger, A., Srebotnik, E., Mach, R.L., Mach-Aigner, A.R., 2016. Identification of the main regulator responsible for synthesis of the typical yellow pigment produced by Trichoderma reesei. Appl. Environ. Microbiol. 82, $6247-6257$.

Dufossé, L., Fouillaud, M., Caro, Y., Mapari, S.A.A., Sutthiwong, N., 2014. Filamentous fungi are large-scale producers of pigments and colorants for the food industry. Curr. Opin. Biotechnol. 26, 56-61.

Eldahshan, O.A., Singab, A.N.B., 2013. Carotenoids. J. Pharmacogn. Phytochem. 2 (1), 225-234.

Elsanhoty, R.M., Al-Turki, I.A., Ramdan, M.F., 2012. Screening of medium components by Plackettt-Burman design for carotenoid production using date (Phoenix dactylifera) wastes. Ind. Crop. Prod. 36, 313-320.

Fautz, E., Reichenbach, H., 1979. Biosynthesis of flexirubin: incorporation of precursors by the bacterium Flexibacter elegans. Phytochem 18, 957-959.

Fautz, E., Reichenbach, H., 1980. A simple test for flexirubin-type pigments. FEMS Microbiol. Lett. 8, 87-91.

Forestier, S., Candau, D., Seyler, N., Elguidj, I., 2004. Composition for Giving the Skin a Coloration Similar to that of a Natural Tan, Based on a Pigment of the Monascus Type, and Uses Thereof. US6740313 B2.

Franceschini, A., Szklarczyk, D., Frankild, S., Kuhn, M., Simonovic, M., Roth, A., Lin, J. Minguez, P., Bork, P., von Mering, C., Jensen, L.J., 2013. STRING v9.1: proteinprotein interaction networks, with increased coverage and integration. Nucleic Acids Res. 41, D808-D815.

Fuchs, S.W., Bozhüyük, K.A., Kresovic, D., Grundamann, F., Dill, V., Brachmann, A.O. Waterfield, N.R., Bode, H.B., 2013. Formation of 1,3-cyclohexanediones and resorcinols catalyzed by a widely occurring ketosynthase. Angew. Chem. Int. Ed. Engl 52, 4108-4112.

Ganapathy, A., Jayavel, S., Natesan, S., 2016. Draft genome sequence of carotenoid producing yellow pigmented Planococcus maritimus MKU009. J. Genomics 4, 23-25.

Han, S., Yang, Y., 2005. Antimicrobial activity of wool fabric treated with curcumin. Dyes Pigments 64, 157-161.

Henríquez, V., Escobar, C., Galarza, J., Gimpel, J., 2016. Carotenoids in microalgae. In: Stange, C. (Ed.), Carotenoids in Nature. Springer International Publishing, Switzerland, pp. 219-237.

Ho, S.H., Xie, Y., Chan, M.C., Liu, C.C., Chen, C.Y., Lee, D.J., Huang, C.C., Chang, J.S. 2015. Effects of nitrogen source availability and bioreactor operating strategies on lutein production with Scenedesmus obliquus FSP-3. Bioresour. Technol. 184, $131-138$.

Hsu, L.C., Hsu, Y.W., Liang, Y.H., Kuo, Y.H., Pan, T.M., 2011. Anti-tumor and antiinflammatory properties of ankaflavin and monaphilone A from Monascus purpureus NTU 568. J. Agric. Food Chem. 59 (4), 1124-1130.

Hsu, W.H., Huang, Y.C., Lee, B.H., Hsu, Y.W., Pan, T.M., 2013. The improvement of ankaflavin isolated from Monascus-fermented products on dyslipidemia in high-fat-diet-induced hamster. J. Funct. Food 5 (1), 434-443.

Hsu, W.H., Lee, B.H., Huang, Y.C., Hsu, Y.W., Pan, T.M., 2012. Ankaflavin, a novel Nrf-2 activator for attenuating allergic airway inflammation. Free Radical Biol. Med. 53, 1643-1651.

Huang, C.H., Pan, J.H., Chen, B., Yu, M. Huang H.B, Zhu, X, Lu, YJ., She, Z.G. Lin, Y.C., 2011. Three bianthraquinone derivatives from the mangrove endophytic fungus Alternaria sp. ZJ9-6B from the South China Sea. Mar. Drugs 9 (5), 832-843.

Jacobson, G. Wasileski, J. 1994. Production of food colorants by fermentation. In: Gabelman, A. (Ed.), Bioprocess Production of Flavour, Fragrance and Color Ingredients. John Wiley \& Sons., New York, pp. 205-237.

Jehlička, J., Osterrothová, K., Oren, A., Edwards, H.G.M., 2013. Raman spectrometric discrimination of flexirubin pigments from two genera of Bacteroidetes. FEMS Microbiol. Lett. 348, 97-102.

Joshi, V.K., Attri, D., Rana, M.S., 2011. Optimization of apple pomace based medium and fermentation conditions for pigment production by Sarcina sp. Indian. J. Nat. Prod. Resour 2 (4), 421-427.

Jou, P.C., Ho, B.Y., Hsu, Y.W., Pan, T.M., 2010. The effect of monascus secondary polyketide metabolites monascin and anaflavin, on adipogenesis and lipolysis activity in 3T3-L1. J. Agric. Food Chem. 58, 12703-12709.

Jung, H., Kim, C., Kim, K., Shin, C.S., 2003. Color characteristics of Monascus pigment derived by fermentation with various amino acids. J. Agric. Food Chem. 51 
1302-1306.

Kamarudin, K.R., Ngah, N., Hamid, T.H.T.A., Susanti, D., 2013. Isolation of a pigmentproducing strain of Staphylococcus kloosii from the respiratory tree of Holothuria (Mertensiothuria) leucospilota (Brandt 1835) from Malaysian waters. Trop. Life Sci. Res. 24 (1), 85-100.

Kämpfer, P., Mclnroy, J.A., Glaeser, S.P., 2015. Chryseobacterium rhizoplanae sp. nov. isolated from the rhizoplane environment. Antonie Leeuwenhoek 107, $533-538$.

Kämpfer, P., Mclnroy, J.A., Glaeser, S.P., 2014. Chryseobacterium zeae sp. nov. Chryseobacterium arachidis sp. nov., and Chryseobacterium geocarposphaerae sp. nov. isolated from the rhizosphere environment. Antonie Leeuwenhoek 105 $491-500$.

Kirti, K., Amita, S., Priti, S., Kumar, A.M., Jyoti, S., 2014. Colorful world of microbes: carotenoids and their applications. Adv. Biol. 13, 2014.

Korumilli, T., Mishra, S., 2014a. Carotenoid production by Rhodotorula sp. on fruit waste extract as a sole carbon source and optimization of key parameters. Iran. J. Chem. Chem. Eng 33 (3), 89-99.

Korumilli, T., Mishra, S., 2014b. Carotenoid production by Bacillus clausii using rice powder as the sole substrate: pigment analyses and optimization of key production parameters. J. Biochem. Technol. 5 (4), 788-794.

Krairak, S., Yamamura, K., Irie, R., Nakajima, M., Shimizu, H., Chim-Anage, P., Yongsmith, B., Shioya, S., 2000. Maximizing yellow pigment production in fedbatch culture of Monascus sp. J. Biosci. Bioeng. 90 (4), 363-367.

Kulkarni, S.S., Bodake, U.M., Pathade, G.R., 2011. Extraction of natural dye from chill (Capsicum annum) for textile coloration. Univers. J. Environ. Res. Tech. 1, 58-63.

Kumar, A., Vishwakarma, H.S., Singh, J., Dwivedi, S., Kumar, M., 2015. Microbia pigments: production and their applications in various industries. Int. J. Pharm. Chem. Biol. Sci. 5 (1), 203-212.

Lee, B.H., Hsu, W.H., Hsu, Y.W., Pan, T.M., 2013a. Dimerumic acid attenuates receptor for advanced glycation endproduct (RAGE) signal to inhibit inflammation and diabetes mediated by Nrf2 activation and promoted methylglyoxal metabolism into D-lactate acid. Free Radic. Biol. Med. 60, 7-16.

Lee, C.L., Kung, Y.H., Wu, C.L., Hsu, Y.W., Pan, T.M., 2010. Monascin and ankaflavin act as novel hypolipidemic and high density lipoprotein cholesterol-raising agents in red mold dioscorea. J. Agric. Food Chem. 58, 9013-9019.

Lee, C.L., Wen, J.Y., Hsu, Y.W., Pan, T.M., 2013b. Monascus-fermented yellow pigments monascin and ankaflavin showed antiobesity effect via the suppression of differentiation and lipogenesis in obese rats fed a high-fat diet. J. Agric. Food Chem. 61, 1493-1500.

Li, D.L., Li, X.M., Wang, B.G., 2009. Natural anthraquinone derivatives from a marine mangrove plant-derived endophytic fungus Eurotium rubrum: structura elucidation and DPPH radical scavenging activity. J. Microbiol. Biotechnol. 19 (7), 675-680.

Mapari, S.A.A., Meyer, A.S., Thrane, U., 2006. Colorimetric characterization for comparative analysis of fungal pigments and natural food colorants. J. Agric Food Chem. 54, 7027-7035.

Mavrodi, D.V., Blankenfeldt, W., Thomashow, L.S., 2006. Phenazine compounds in fluorescent Pseudomonas Spp. biosynthesis and regulation. Annu. Rev. Phytopathol. 44, 417-445.

Mazeyar, P., 2009. An environmentally method for dyeing rug pile using fruit waste colorant. Res. J. Chem. Environ. 13 (3), 49-53.

Mc Bride, M.J., Xie, G., Martens, E.C., Lapidus, A., Henrissat, B., Rhodes, R.G., Goltsman, E., Wang, W., Xu, J., Hunnicutt, D.W., Staroscik, A.M., Hoover, T.R. Cheng, Y.Q., Stein, J.L., 2009. Novel features of the polysaccharide-digesting gliding bacterium Flavobacterium johnsoniae as revealed by genome sequence analysis. Appl. Environ. Microbiol. 75, 6864-6875.

Meddeb-Mouelhi, F., Moisan, J.K., Bergeron, J., Daouts, B., Beauregard, M., 2016 Structural characterization of a novel antioxidant pigment produced by a photochromogenic Microbacterium oxydans strain. Appl. Biochem. Biotechnol. 180, 1286-1300

Mezzomo, N., Ferreira, S.R.S., 2016. Carotenoids functionality, sources and processing by supercritical technology: a review. J. Chem., 3164312

Mohana, D.C., Thippeswamy, S., Abhishek, R.U., 2013. Antioxidant, antibacterial and ultraviolet protective properties of carotenoids isolated from Micrococcus spp. Radiat. Protect. Environ. 36 (4), 168-174.

Mojib, N., Philpott, R., Huang, J.P., Niederweis, M., Bej, A.K., 2010. Antimycobacterial activity in vitro of pigments isolated from Antarctic bacteria. Antonie Leeuwenhoek 98, 531-540.

Mulders, K.J.M., 2014. Phototrophic pigment production with microalgae: biologica constraints and opportunities. J. Phycol. 50, 229-242.

Nasrabadi, M., Razavi, S., 2011. Optimization of $\beta$-carotene production by a mutant of the lactose-positive yeast Rhodotorula achenorium from whey ultrafiltrate. Food. Sci. Biotech. 20, 445-454.

Neeraj, N., Neera, M., Sayan, C., 2011. Microbial pigments with health benefits-a mini review. Trends Biotechnol. 4 (2), 157-160.

Panesar, R., Kaur, S., Panesar, P.S., 2015. Production of microbial pigments utilizing agro-industrial waste: a review. Curr. Opi. Food. Sci. 1, 70-76.

Pankaj, V.P., Kumar, R., 2014. Microbial pigment as a potential natural colorant for contributing as mankind. Res. Trends. Mol. Biol. 85-98.

Parekh, S., Vinci, V.A., Strobel, R.J., 2000. Improvement of microbial strains and fermentation process. Appl. Microbiol. Biotechnol. 54 (3), 287-301.

Peix, A., Berge, O., Rivas, R., Abril, A., Velázquez, E., 2005. Pseudomonas argentinensis sp. nov., a novel yellow pigment-producing bacterial species, isolated from rhizospheric soil in Cordoba, Argentina. Int. J. Syst. Evol. Microbiol. 55, $1107-1112$.

Poorniammal, R., Parthiban, M., Gunasekaran, S., Murugesan, R., Thilagavathi, G., 2013. Natural dye production from Thermomyces sp. fungi for textile application. Indian. J. Fibre. Text 38, 276-279.

Poplawsky, A.R., Urban, S.C., Chun, W., 2000. Biological role of xanthomonadin pigments in Xanthomonas campestris pv. Campestris. Appl. Environ. Microbiol. 66 (12), 5123-5127.

Prashanti, K., Suryan, S., Varalakshmi, K.N., 2015. In vitro anticancer propertiy of yellow pigment from Streptomyces griseoaurantiacus JUACT 01. Braz. Arch. Biol. Technol. 58 (6), 869-876.

Radhakrishnan, M., Gopikrishnan, V., Vijayalakshmi, G., Kumar, V., 2016. In vitro antioxidant activity and antimicrobial activity against biofilm forming bacteria by the pigment from Desert soil Streptomyces sp D25. J. Appl. Pharm. Sci. 6 (06), $148-150$.

Romanenko, L.A., Tanaka, N., Svetashev, V.I., Kurilenko, V.V., Mikhailov, V.V., 2015. Flavobacterium maris sp. nov, isolated from shallow sediments of the Sea of Japan. Arch. Microbiol. 197, 941-947.

Sajilata, M.G., Singhal, R.S., Kamat, M.Y., 2008. The carotenoid pigment zeaxanthin. Compr. Rev, Food Sci. Food Saf. 7, 29-41.

Schöner, T.A., Fuchs, S.W., Schönau, C., Bode, H.B., 2014. Initiation of the flexirubin biosynthesis in Chitinophaga pinensis. Microb. Biotechnol. 7 (3), 232-241.

Schöner, T.A., Kresovic, D., Bode, H.B., 2015. Biosynthesis and function of bacterial dialkylresorcinol compounds. Appl. Microbiol. Biotechnol. 99, 8323-8328.

Shahid, M., Islam, S., Mohammad, 2013. Recent advancements in natural dye applications: a review. J. Clean. Prod. 53, 310-331.

Shindo, K., Misawa, N., 2014. New and rare carotenoid isolated from marine bacteria and their antioxidant activities. Mar. Drugs 12, 1690-1698.

Su, N.W., Lin, Y.L., Lee, M.H., Ho, C.Y., 2005. Ankaflavin from Monascus-fermented red rice exhibits selective cytotoxic effect and induces cell death on Hep G2 cells. J. Agric. Food Chem. 53 (6), 1949-1954.

Taskin, M., Erdal, S., 2011. Production of carotenoids by Rhodotorula glutinis MT-5 in submerged fermentation using the extract from waste loquat kernals as substrate. J. Sci. Food Agric. 91, 1440-1445.

Tuli, H.S., Chaudhary, P., Beniwal, V., Sharma, A.K., 2014. Microbial pigments as natural color sources: current trends and future perspectives. J. Food Sci. Technol. 52 (8), 4669-4678.

Uddin, M.G., 2014. Effects of different mordants on silk fabric dyed with onion outer skin extracts. J. Text 2014, 1-8.

Umadevi, K., Krishnaveni, M., 2013. Antibacterial activity of pigment produced from Micrococcus luteus KF532949. J. Chem. Anal. Sci. 4 (3), 149-152.

Valduga, E., Ribeiro, A.H.R., Cence, K., Colet, R., Tiggemann, L., Zeni, J., Toniazzio, G., 2014. Carotenoids production from a newly isolated Sporidiobolus pararoseus strain using agroindustrial susbtrates. Biocatal. Agric. Biotechnol. 3, 207-213.

Velmurugan, P., Kamala-Kannan, S., Balachndar, V., Laksmanaperumalsamy, P., Chae, J.C., Oh, B.T., 2010. Natural pigment extraction from five filamentous fungi for industrial applications and dyeing of leather. Carbohydr. Polym. 79, 262-268.

Velu, S., Velayutham, V., Manikam, S., 2016. Optimization of fermentation media for xanthan gum production from Xanthomonas campestris using Response Surface Methodology and Artificial Neural Network techniquies. Indian J. Chem. Technol. 23, 353-361.

Venil, C.K., Aruldass, C.A., Dufossé, L., Zakaria, Z.A., Ahmad, W.A., 2014a. Current perspective on bacterial pigments: emerging sustainable compounds with coloring and biological properties for the industry - an incisive evaluation. RSC Adv. 4, 39523-39529.

Venil, C.K., Khasim, A.R., Aruldass, C.A., Ahmad, W.A., 2016b. Microencapsulation of flexirubin-type pigment by spray drying: characterization and antioxidant activity. Int. Biodeterior. Biodegrad. 113, 350-356.

Venil, C.K., Nordin, N., Zakaria, Z.A., Ahmad, W.A., 2014b. Chryseobacterium artocarpi sp. nov., isolated from the rhizosphere soil of Artocarpus integer. Int. J. Syst. Evol. Microbiol. 64, 3153-3159.

Venil, C.K., Sathiskumar, P., Malathi, M., Usha, R., Jayakumar, Yusoff, A.R.M., Ahmad, W.A., 2016a. Synthesis of flexirubin-mediated silver nanoparticles using Chryseobacterium artocarpi CECT 8497 and investigation of its anticancer activity. Mater. Sci. Eng. C 59, 228-234.

Venil, C.K., Zakaria, Z.A., Ahmad, W.A., 2013. Bacterial pigments and their applications. Process Biochem. 48, 1065-1079.

Venil, C.K. Zakaria, Z.A., Ahmad, W.A., 2015. Optimization of culture conditions for flexirubin production by Chryseobacterium artocarpi CECT 8497 using response surface methodology. Acta Biochim. Pol. 62 (2), 185-190.

Wang, Y.R., Liu, S.F., Shen, Y.C. Chen, C.L., Huang, C.N., Pan, T.M., Wang, C.K., 2017. A randomized, double-blind clinical study to determine the effect on ANKASCIN 568 plus on blood glucose regulation. J. Food Drug Anal. 5 (2), 409-416.

Yang, Y., Liu, B., Du, X., Li, P., Liang, B., Cheng, X., Du, L., Huang, D., Wang, L., Wang, S., 2015. Complete genome sequence and transcriptomics analyses reveal pigment biosynthesis and regulatory mechanisms in an industrial strain, Monascus purpureus YY-1. Sci. Rep. 5, 8331.

Yolmeh, M., Khomeiri, M., 2016. Using physical and chemical mutagens for enhanced carotenoid production from Rhodotorula glutinis (PTCC 5256). Biocatal. Agric. Biotechnol. 8, 158-166.

Yolmeh, M., Khomeiri, M., Ghorbani, M., Ghaemi, E., Ramezanpour, S.S., 2017. High efficiency pigment production from Micrococcus roseus (PTCC 1411) under 
ultraviolet irradiation. Biocatal. Agricul. Biotechnol. 9, 156-161.

Yongsmith, B., Thongpradis, P., Klinsupa, W., Chantrapornchai, W. Haruthaithanasan, V., 2013. Fermentation and quality of yellow pigments from golden brown rice solid culture by a selected Monascus mutant. Appl. Microbiol. Biotechnol. 97, 8895-8902.

Yusuf, M., Shahid, M., Khan, M.I., Khan, S.A., Khan, M.A., Mohammad, F., 2011
Dyeing studies with henna and madder: a research on effect of tin (II) chloride mordant. J. Saudi. Chem. Soc. 19 (1), 64-72.

Zhou, B., Wang, J., Pu, Y., Zhu, M., Liu, S., Liang, S., 2009. Optimization of culture medium for yellow pigments production with Monascus anka mutant using response surface methodology. Eur. Food Res. Technol. 228 (6), 895-901. 